Ann. Génét. Sél. anim., I978, 10 (2), 275-307.

\title{
Informations
}

\section{Twenty years of research in beef cattle breeding in France (1956-1976)}

\author{
B. VISSAC $\left({ }^{*}\right)$ \\ Département de Génétique Animale, I.N.R.A., \\ Centre National de Recherches Zootechniques, \\ Jouy-en-Josas, 78350 , France
}

\section{Contents}

\author{
I. - Introduction \\ 2. - Genetic variation
}

2.I. - Polymorphisms

2.II. - Chromosomes

2.I2. - Genes

2.I2I. - Biochemical mutants

2.122. - Visible mutants

2.2. - Polygenic variation

2.21. - Preliminary research on growth traits

2.22. - Analysis of direct and maternal effects

2.23. - Adaptability

(*) In cooperation with POPEscu (cytogenetics), Grosclaude (biochemical polymorphisms), LAUvergne (visible mutants), MÉnissier, Brbe, Colleau, Foulley and Frebi.ing (polygenic traits). 


\section{3. - Breeding improvement}

3.I. - Practical breeding schemes

$$
\begin{aligned}
& \text { 3.31. - Schemes for terminal crossing } \\
& \text { 3.32. - Schemes for reproductive traits }
\end{aligned}
$$

\section{2. - Crossbreeding systems}

3.3. - Optimal use of vegetable land resources by beef cattle

$$
\begin{aligned}
& \text { 4. - Conclusion } \\
& \text { 5. - References }
\end{aligned}
$$

\section{1. - Introduction}

Interest for French research work in the field of beef cattle breeding is quite general. French beef cattle populations, which first appeared well fitted to the new requirements of intensive production systems and market demand are now, for most of them, widespread on all the continents. France being located at the meeting point of the main physical areas and human influences in Western Europe (oceanic, alpine, continental and mediterranean) its cattle industry is concerned with a wide variety of populations, environments and production systems. Further the early development of AI and reproduction control in France where the proportion of cows inseminated is among the highest in the world, chiefly in suckling herds, makes it easier to manage more efficient breeding programs in small holding. farms. For all these reasons French research work on beef cattle breeding could lead to some original ideas and results in a field where scientists have limited the scope of studies to specific breeds (Hereford, Brahman, Holstein) under extensive management systems where the matings are chiefly by natural service.

The first studies on beef cattle breeding were made in France around r956: they were devoted to measures of growth rate in farms and of carcass quality in slaughter houses. Some Charolais breeders of the Nièvre area (Syndicat de contrôle des performances des éleveurs de la Nièvre) and of the AI center of Soual (AveyronTarn) in the zone where beef sires where mainly used for terminal crossing, were the first organization conducting experimental breeding programs in connection with research workers of the "Institut National de la Recherche Agronomique" (I.N.R.A.). After I963, facilities became available in France for the performance testing and progeny testing of AI bulls, first on fattening traits, then in 1967 to r97o on fertility and maternal ability of their female progeny. Such testing stations were complementing field data, giving more complete and accurate information for studies on the genetic variation of quantitative traits in beef herds. Scientists had to integrate all this information into decision procedures at the level of breeds and AI breeding units. This research work was recognized 
TABLE I

Scientific $(S)$ and technical $(T)$ staff of the department of animal genetics involved in research works on beef cattle breeding in 1976

Équipe scientifique et technique du Département de génétique impliquée dans les travaux sur les bovins à viande en 1976

\begin{tabular}{|c|c|c|c|c|c|}
\hline \multicolumn{2}{|c|}{ Research or technical field } & Laboratory & Location & $\mathrm{S} / \mathrm{T}$ & Name \\
\hline $\begin{array}{l}\text { Poly- } \\
\text { mor- } \\
\text { phisms }\end{array}$ & $\begin{array}{l}\text { Cytogenetics } \\
\text { Abnormalities and coat } \\
\text { color patterns } \\
\text { Blood groups and bio- } \\
\text { chemical polymorphisms }\end{array}$ & $\begin{array}{c}\text { Lab. de } \\
\text { cytogénétique } \\
\text { Lab. de génétique } \\
\text { factorielle } \\
\text { Lab. de génétique } \\
\text { biochimique }\end{array}$ & $\begin{array}{l}\text { Jouy-en-Josas } \\
\text { Jouy-en-Josas } \\
\text { Jouy-en-Josas } \\
\text { Jouy-en-Josas }\end{array}$ & $\begin{array}{l}\mathrm{S}^{* *} \\
\mathrm{~S}^{*} \\
\mathrm{~S}^{*} \\
\mathrm{~T}\end{array}$ & $\begin{array}{l}\text { POPESCU P. } \\
\text { LAUVERGNE J.J } \\
\text { GROSCLAUDE F. } \\
\text { HOULIER G. }\end{array}$ \\
\hline 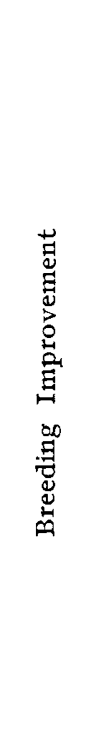 & \begin{tabular}{|l|} 
Efficiency of breeding \\
schemes \\
Breeding methods \\
methods of analysis of \\
genetic variability \\
Analysis of genetic varia \\
bility Fitness traits \\
- double muscling \\
Growth and feed effi- \\
ciency \\
Management of breeding \\
schemes and experimen- \\
tal farms \\
Testing stations (analy- \\
sis of data) \\
Field crossbreeding ex- \\
periments (E.E.C.) \\
Management of the \\
double muscling herds \\
Management of the cross \\
breeding experiments \\
Breeding in harsh envi- \\
ronments - adaptability
\end{tabular} & $\begin{array}{c}\text { Station de généti- } \\
\text { que quantitative } \\
\text { et appliquée } \\
" \\
" \\
" \\
" \\
" \\
" \\
\text { Station } \\
\text { d'Amélioration } \\
\text { génétique }\end{array}$ & $\begin{array}{c}", \\
" \\
" \\
" \\
\text { Carmaux } \\
\text { Avord } \\
\text { Toulouse }\end{array}$ & $\begin{array}{l}\mathrm{T} \\
\mathrm{T}^{* *} \\
\mathrm{~T} \\
\mathrm{~T} \\
\mathrm{~T} \\
\mathrm{~S}^{*}\end{array}$ & $\begin{array}{l}\text { FOULLEY J. L. } \\
\text { MENISSIER F. } \\
\text { BONAITI B. } \\
\text { FREBLING J. } \\
\text { GAILLARD J. } \\
\text { SAPA J. } \\
\text { FABRE G. P. } \\
\text { PERREAU B. } \\
\text { BIBE B. }\end{array}$ \\
\hline
\end{tabular}

$\left({ }^{*}\right)$ These scientists are working half time on beef cattle breeding.

(**) These scientists and technicians working in Laboratories of the Department of Animal Genetics belong to professional organizations: U.N.C.E.I.A. (POPESCU) and I.T.E.B. cattle breeding section (GAIILARD).

in the "Breeding Act " voted in I 967 by the French parliament: the first experimental breeding organizations were expanded at the national level. More recently (I967-I968) experimental breeding herds directly controlled by INRA were founded : Le Pin (Western Normandy), Bourges (Center North) and Carmaux (South West); they were all devoted to more detailed analyses of breeds and crossbreeding strategies predicting the orientation of the actual beef breeding programs :

- Le Pin au Haras for dairy cattle breeding (milking herd) 
- Bourges for beef cattle breeding (suckling herd) muscling).

Since I96I, in cooperation with the Istituto Zootecnico e Caseario per la Sardegna in Sassari, we have broadened the field of our activities to the studies of beef cattle breeding for marginal areas. More recently we have also been involved in studies of beef cattle breeding in French overseas tropical islands (Réunion), in Ivory Coast through the "Institut d'Élevage et de Médecine Vétérinaire Tropical" (IEMVT) and in other parts of the world through foreign research institutions. At the same time, research work has been done in the fields of factorial genetics (I960), biochemical genetics (I957) and later on cytogenetics (I967). In each of these fields both scientific and applied research are achieved in relation with breeding organizations. The list of scientific and technical staff of the Department of animal Genetics involved in these researchs is given in table $I$.

Though there is some interest to put forward this chronological trend in the French research activities on beef cattle breeding, we shall first present the results obtained and ideas developed in a more classical way : the genetic variation concerning chromosomes, single genes and quantitative effects of polygenes, then we shall deal with the breeding strategies and selection methods of cattle populations to increase beef production.

\section{2. - Genetic variation}

French cattle breeds come from local strains primarily adapted to specific environments and selected by breeding societies, for various production traits: milk, meat and draft, before the end of the last century. Among external traits considered here, the coat color has been a major selection goal, animals of a given color pattern reared on the most efficient environments being favored in the selection process. Descriptions of these populations and breeds have been given previously by DE LAPPARENT and QUITTET.

Today they can be classified in the following way:

- dual purpose breeds which constitute the majority of animals in the dairy herds widespread in a great part of the country and chiefly in the West (Normande), in the North (French Friesan) and in the East (Montbéliarde : the dairy type of the French Simmental population);

- dual purpose breeds of local extension in dairy herds (Abondance, Tarine) and whose number is declining rapidly (Brune des Alpes);

- dual purpose breeds of larger size, more and more selected for beef traits and reared in suckling herds: Maine-Anjou and Pie-Rouge de l'Est (beef type of the French Simmental population);

- beef breeds: Charolaise, Limousine and Blonde d'Aquitaine formerly used for draft which result in a high muscular development;

- multiple purpose breeds: milk, beef and draft (Salers, Aubrac) or beef and draft (Gasconne) from mountainous areas, the former ones being less and less milked.

We must also mention the rare breeds (only several hundred or thousand heads): those specialized for milk in the North: Flamande (Flandres), Vosgienne 
(Vosges), Villard de Lans (Alpes) and Bretonne Pie-Noire, small sized (Brittany); those selected also for meat and draft: Parthenaise, Bazadaise (Center West), Blonde des Pyrénées; those reared outside all the year round in the Mediterranean area : Corsican breed, Camargue (used for bull's fighting).

\section{I. - Polymorphisms}

\section{II. - Chromosomes}

A description of somatic chromosomes was first done by $\operatorname{PopESCU}(I, 7)$ on Bos taurus and Bos grunniens with special reference to the comparison between chromosomes and autosomes (8). Concerning meiotic chromosomes PoPESCU $(I, 9)$ estimated the number of chiasma per cell $(I, I 0)$ and the coefficient of terminalization: $0.6 \mathrm{I}$, the number of crossing over per bivalent being a round roo in agreement with FORD's formula. An abnormally high percentage of polyploid cells has been observed at several steps of the meiosis: according to FORD, they seem to result from an artefact (I6). Several studies are now under way to apply the banding procedures: with the $\mathrm{C}$ coloration $(4,5,7)$ it has been found that a polymorphism exists in the amount of heterochromatin in the first two pairs of autosomes. The exchanges between chromatids has been analyzed through the BUDR treatment $(6,26)$ : the average number of exchanges per chromosome seems to be similar for man and for cattle; it is directly proportional to the length of the chromosomes.

A survey of chromosome polymorphism in the French cattle populations was prepared by POPESCU and CRIBIU: Laboratoire de Cytogénétique (INRA, Union Nationale des Coopératives d'Élevage et d'Insémination Artificielle) located at Jouy-en-Josas $(\mathrm{I}, 3$ ), by DARRÉ and QUEINNEC (École Nationale Vétérinaire de Toulouse) (2I). Both laboratories have observed the Robertsonian translocation (I /29, first described on cattle by GuTavsson). In around I 800 animals recorded by POPESCU (25) it has been found that this abnormality is chiefly expressed in the Charolaise, Limousine and Blonde d'Aquitaine breeds: between 4 to 8 p. Ioo animals affected in a non random sample of 500 recorded; 2 cases have also been observed in the Montbeliarde breed (out of roo animals recorded), the French Friesian and Normande breed being free of this translocation (550 animals recorded). The resulting new chromosome seems to be a monocentric one $(4,5,7)$ which lead to the hypothesis of an old origin of the translocation. It is transmitted as a simple Mendelian and it significantly affects the fertility of the female progeny from translocated sires (40 p. Ioo decrease in the conception rate). From an analysis of meiotic chromosomes of translocated bulls, POPESCU found around I 9 p. roo of non equilibrated metaphasis which could produce after a normal development, letal embryos and then reduce the fertility of affected bulls. Many facts indicate that, in France, this translocation seems to appear more frequently in breeds (see above), strains and lines selected for larger size and muscular development. Lastly, a new Robertsonian translocation concerning two chromosomes between the $10^{\text {th }}$ and $22^{\text {th }}$ pairs has been observed on an animal affected by the previous one ( $\mathrm{I} 8$ ). POPESCU also described a case of significantly longer $\mathrm{Y}$ in a Charolais bull (I7); using different banding procedures he has analyzed a pericentric inversion affecting a Norman bull and transmitted to $50 \mathrm{p}$. 100 of its female progeny $(14,27)$.

Both laboratories are also studying the chimerism on leucocytes from heterosexual twins. In about rooo AI bulls, the frequency of animals expressing some 
chimerism has been estimated to be I.22 p. Ioo, that of female cells from affected animals varying between 6.25 and Ioo p. Ioo. The fertility of two extreme bulls has been analyzed: one was over the average of the AI center, the other was significantly lower with a marked deviation of the sex-ratio favouring female calves.

\subsection{2. - Genes}

\section{I2I. - Biochemical mutants}

\section{a) Blood groups}

Research work on bovine blood groups started at Jouy-en-Josas in I956; the first goal was to create and develop a typing to which breeders and breeding associations could submit cases of doubtful identification and parentage control. In this field the two main objectives were to develop the knowledge on cattle blood group systems and to establish the specific blood groups of French breeds.

A new blood group system, the $I^{\text {th }}$ one, named $T^{\prime}$, was discovered in I965 (33). In addition, the 80 or more reagents produced in the laboratory have led to improved discrimination within the $B, C, F$ and $S$ systems $(29,31,34,35,36,37)$. Results on the S system are particularly spectacular since it has been shown that the system involves at least $\mathrm{I} 7$ alleles instead of the 5 considered initially $(29,3 \mathrm{I}, 34,35)$. Its characteristics are very variable from one breed to another and it effectively differentiates Northern French breeds from the Southern ones.

Data on blood groups have been gathered from most French breeds, and now work is still being done one rare breeds (Vosgienne, Villard de Lans). A phylogenic study will be carried out on all the related information. Until now, results have only been published on the genetic variability and the phylogenic situation of the Montbéliarde $(28,30)$ and the Flamande $(38)$ breeds. The study on the first breed (I960) showed that the genetic variability of the breed remained very large and that was lecoming genetically distinct from the Simmental. The Flamande, which was formerly considered as a population of small genetic size, was found to possess in I968 a genetic variability similar to the most widespread French Friesian breed (F.F.P.N.).

\section{b) Antigens of white cells and fluids}

Immuno-genetic studies have been devoted to antigens in serum and saliva (39) and on platelets (4I, 42). In addition, hetero and iso-antiglobulinic reactions were performed in cattle; the first type of reaction gave evidence of antigenic factors non detectable by hemolysis the second type was used to determine inhibitory serum-groups $(40,43,4 \mathrm{I}, 45,46)$. The genetic of 3 inhibitory factors was studied $(47,48)$; two are present on immunoglobulins and are similar to human $\mathrm{G}_{m}$ factors; the third one is related to the soluble $\mathrm{J}$ substance. It is possible, using several refined methods, to subdivide this $\mathrm{J}$ substance.

In man and several laboratory species, the major histocompatibility system, which concerns lymphocyte antigens, is closely linked to genes involved in control of the immune response. A study of cattle lymphocyte groups was started in cooperation with R.I. SPOONER (Animal Breeding Research Organization) (A.B.R.O. Edinburgh) and M. VAIMAN (Commissariat à l'Énergie Atomique). At the present time, more than 30 specific reagents have been obtained in a pure state. 


\section{c) Antigens of spermatozoa}

Some antigenic characteristics of bull spermatozoa were investigated in order to establish if populations of spermatozoa could be fractionated on the basis of these properties (49). A technique for the purification of spermatozoa was first described (5I). Further work led to the conclusion that several blood group antigens of the S system were present on spermatozoa (50). However, the immunization of heifers with spermatozoa was unsuccessful $(52)$.

\section{d) Milk proteins}

Combined biochemical and genetic research has been undertaken since I964 in order to elucidate the genetic determinism of the main protein components of milk.

A survey of the electrophoretic polymorphism of $\alpha$-lactalbumin, $\beta$-lactoglobulin, $\alpha_{S_{1}} \bar{\beta}$ and $\overline{\mathrm{K}}$ caseins has been made in ${ }_{5}$ French bovine breeds, in some African and Asiatic bovine breeds and in African and Malagasy zebus $(56,53,65)$. A new variant of $\alpha_{\mathrm{s}_{1}}$ casein was discovered in the Flamande breed and later in several other breeds (55). In addition, a new variant of $\beta$-lactoglobulin has been found to occur in the Montbéliarde (55). The data on electrophoretic polymorphisms have the same value for phylogenic studies as those on blood groups. The alterations specific to all the genetic variants of $\alpha_{\mathrm{s}_{1}} \bar{\beta}$ and $\overline{\mathrm{K}}$ caseins were determined $(57,58,59,60,61,64,65)$. It was shown that the common variants were the same in zebu and in bovine; this indicates a close genetic similarity between the two species (63).

The genetic determinism of $\alpha_{\mathrm{S}_{1}}, \beta$ and $\mathrm{K}$ caseins was found to be original since these proteins are synthesized by a group of three closely linked loci; this situation is comparable with the structure known in modern biology as an "operon " and it may be supposed that it plays a role in the overall synthesis mechanisms of these proteins $(53,54,56,62,65)$. Recently it was shown that the fourth casein species $\left(\alpha_{S_{2}}\right)$ is also synthesized by a locus closely linked to the $\alpha_{\mathrm{s}_{1}}, \beta, \mathrm{K}$ cluster; the 4 caseins are thus controlled by a group of 4 loci behaving in fact like a single hereditary unit. The genetic analysis of this unit in cattle populations shows the existence of a strong linkage desequilibrium between these loci (65). Bovine caseins thus represent the only concrete situation where the evolution of relationships between closely linked loci under the effect of recombination, genetic drift and selection may be evaluated empirically (65).

Further, the study of several genetic variants of caseins have provided clues for understanding the mechanisms of phosphorylation of these proteins $(60,62$, $64,65)$.

\subsection{2. - Visible mutants}

\section{a) Coat color}

A genetic study of the variation in the coat color patterns of French, Italian and Swiss cattle breeds is now underway by LAUVERGNE $(68,69,75,76)$; biochemical analyses of the maelanin were done in connection with Misucara et al.: Naples (77).

\section{b) Hereditary defects}

Systematic studies were completed on abnormal defects which appear in the progeny of AI bulls when a genetic determinism is suspected (LAUVERGNE). 
Out of several studies involving cases of polydactyly (84) and hypotrichosis (90) in the Norman breed, amputation (84) and bulldog (87) in the Friesian, hydrocephaly $(89)$ in the Limousin, two types of genetic defects have been analysed more in detail. The probatocephaly (also named " sheep head "), observed only in the progeny of a Limousin bull, is a subletal abnormality, death occurring during the embryonic life (around I 5 p. Ioo of ova), the fetal stage and after birth. From field data and several types of experimental planned matings, it appears that this trait is determined by a dominant gene with incomplete penetrance : $20 \mathrm{p}$. I00 of the ova $(9 \mathrm{I}, 94)$. The syndrom of arthrogryposis and palatoschisis (SAP) in the Charolaise population is generally expressed at the same time by a cleft palate and arthrogryposis of legs. It is due to a recessive gene, the frequency of which, under several hypotheses, is around 0,20 with a very low penetrance $(0.12)$ in both sexes $(92,98)$. The persistance of this gene, however unfavoured by natural selection, may be explained by a superiority of heterozygotes for productive traits, but at present, nothing has been found in France to support this hypothesis. An international project coordinated by LAUVERGNE is now in progress on this defect. Further, IAUVERGNE and LFFORT (79) have derived a general model to express the frequency and the penetrance of the gene at the equilibrium state from the analysis of progeny testing of AI bulls.

\section{c) Horns}

A polled mutant which seems to be dominant with incomplete penetrance and variable expressivity has been observed 6 years ago in a Charolais pedigree herd; from different kinds of matings observed in this herd it is now questionable whether this mutant can have a negative effect on fitness and productive traits in general or not. This mutant which seems to be phenotypically different from that observed in Aberdeen Angus or Hereford could have some interest for selection in large sized beef cattle.

\section{d) Double muscling (DM)}

Detailed studies have been done since 1960 on double muscling which affects all French beef breeds, its expression being less evident in the Limousin (97, Ioo, IOI, I02, I03, I04, I05). The incidence of this trait on growth (I07, III), reproduction (II2), adaptability (IIO) and maternal ability (III) has been analyzed chiefly in Charolais. Double muscling is influencing the following traits :

I. - the shape of growth curve: higher birth weight and growth rate before 3.4 months; lower growth rate after weaning and probably delayed age at body maturity;

2. - body and carcass composition (between tissues and within tissues): gradients of muscular hypertrophy and skeleton hypotrophy have been described;

3. - the adaptation to nutritional (low adaptability to roughages), climatic (low heat tolerance) and physical stresses;

4. - the fertility and chiefly the puberty which is delayed in both sexes;

5. - the maternal ability: the calving problems are mainly the consequences of the feto-maternal disequilibrium in size (item I) and morphology (item 2); these is also a lack of maternal behaviour in dams at calving, after calving and during the suckling period, milk production being sharply lowered;

6. - the vitality and viability of calves: heart defects and respiratory diseases are the most frequent causes of death. 
Studies on the genetic determinism are difficult, the variation of expressivity in DM being large and partly related to the sensitivity to various environmental stresses. Attempts have been made to establish scoring systems and indexes using live and carcass measurements in order to find a more objective and reliable recording system. Most of results from French studies on the Charolaise breed are in agreement with the hypothesis of a major gene effect with incomplete penetrance: $90 \mathrm{p}$. Ioo of progeny calves from matings $\mathrm{DM} \times \mathrm{DM}$ are affected; Io $\mathrm{p}$. Ioo in the case of DM $\times$ Normal or Normal $\times$ DM matings, this percentage being positively related to the muscularity of the sample of normal animals (IOO, I I). It seems further that the muscularity of normal animals from DM $\times$ Normal matings is intermediate between that of normal and DM animals.

The path from the gene to the traits has been explored at different levels : muscular hypertrophy is chiefly due to a hyperilasia of muscular fibers which seems to be more or less intense for each muscle according to its relative degree of hypertrophy (I06). This fact together with the higher percentage of polyploid somatic cells (leucocytes) indicates the existence of disorders in the cell division. The differences occurring in the organization and chemical composition of the connective tissue have been analyzed: its lower amount is related to a smaller quantity of collagen presenting some metabolic specificity.

a) A higher urinary excretion of hydroxyprolin might indicate a larger collagen degradation or a lack of prolin for its synthesis leading to a more soluble type.

b) A lower rate of collagen sysnthesis might also be due to a reduction of the respiratory capacity in DM animals (IO2). Further, difference in the structure of the nephron could explain a specific filtration ability of DM for particular blood components (I08).

Due to the numerous organic effects of double muscling it seems that the gene is acting very early in the embryonic life.

Research work in this field is increasingly devoted to the description and transmission of the trait in relation to its practical use for the beef industry: improving the amount and quality of meat in crossing schemes and chiefly through terminal crossing: see further (II6, II7, II8, II9, I20).

\section{2. - Polygenic variation}

\subsection{I. - Preliminary research on growth traits (I27 to $\mathrm{I} 4 \mathrm{O}$ )}

The world trend of the demand for lean meat brings into focus the interest of French beef breeds whose muscular development had been favored by selection for draft and beef production. These breeds are now used in crossbreeding all over the world to increase the beef potential of small sized hardy, dairy or beef cow populations. A similar trend was already noticed around I950 in S. W. and Central France with dual purpose and multiple purpose cow populations no longer used for draft or milking: beef crossing gave to farmers a short term opportunity to convert milk into meat through veal and young bull production systems.

This situation explains the former interest (I960) for comparing the genetic differences of growth potential between beef breeds in pure breeding and crosses. The superiority of the Charolaise breed in this respect appeared more marked when the nutritional environment was better (maternal ability of dams in terminal 
crossing with beef sires of other breeds). For a given growth potential, the Limousin breed (or Limousin cross) expresses a larger muscling and a better feed efficiency which is related to a lower body fat content. Blonde d'Aquitaine and Piemontese animals generally lie in an intermediate position between Charolaise and Limousine for all these traits. The within-breed variation of the growth potential of Charolais and Limousin calves before weaning has been analyzed on field data in purebred (pedigree herds) and crossbred (commercial herds using beef sires for terminal crossing through AI) (I30, I34, I66). All traits involved in the direct effect of genes on growth rate and conformation score appear more variable in Charolais, the variation of growth rate independently of birth weight is larger in Limousin. Furthermore, significant genetic differences in Charolais are occurring between zones (they are related to a geographical variation in the muscular development and frequency of double muscling in the breeding area of the Charolais) and between pedigree herds for growth rate in the Limousin (I3I).

These studies on growth are now developed in relation with the selection of paternal breeds and strains for terminal crossing. They involve the overall genetic analysis of the growth curve up to slaughtering, feed efficiency and morphology in their effects on calving ability and carcass value.

\subsection{2. - Analysis of direct and maternal effects ( $\mathrm{I} 4 \mathrm{I}$ to $\mathrm{I} 62$ )}

Overall comparisons between French cattle breeds used in beef herds (Charolaise, Limousine, Salers, Aubrac) and between breeding types (double muscle and Normal Charolaise) indicated, around 1965 , several genetic antagonisms between muscular development and some components of fitness. This also appeared when genetic comparisons were done between Charolaises strains now existing in different countries and selected under different goals and management systems, all of them being imported (I53) after IgIo from the same French population. The more intensive the system and the higher the muscular growth, the lower are the fitness traits and adaptability.

Such results lead to analyzing the between and within-breed variation of direct and maternal effects of genes for each component of the overall efficiency. Several crossbreeding experiments have been done with the aim of:

I. - comparing the paternal and maternal values of hardy, dairy and beef breeds on hardy cow populations in Sardinia: Sarda and Modicana and Southern France: Gasconne and Aubrac (I73-209-2II);

2. - analyzing the overall genetic variation in a factorial experiment involving the Charolaise, Maine-Anjou and Limousine breeds, a sample or pure Hereford being used as a control ( 178$)$;

3. - performing more detailed analyses on the within-breed variation using data from the progeny test stations of AI beef sires on the value of their heifer progeny in an intensive reproduction system: first calving at 2 years (Charolaise, Limousine, Blonde d'Aquitaine) (I62).

First results obtained between hardy and beef breeds as well as within the Charolaise confirm the genetic antagonism between the direct effect of genes on the muscular development and all the maternal effects in fluencing the fitness traits.

The attention of research workers has notably been drawn upon these last traits that are particularly depressed in French beef breeds due to the extreme 
selection in favor of muscular growth and to the confined environment in which this selection has been accomplished. This problem is now important for the adaptation of French beef animals to more extensive management systems. The most comprehensive studies have been devoted to calving ability (I 46 to I6I). This trait is determined by incompatibilities between the relative dimensions of the fetus and the pelvic opening of the dam at birth: they are expressed under threshold effects. The genetic variation of the sire and dam components of calving ability have been estimated in purebreds and crossbreds. Some studies have also been devoted to the fertility of heifer and cow and to the endocrinological effects: Particular attention has been paid to twinning ability, the level of which seems to be the highest in Charolais and Maine-Aniou breeds (I45): the natural variation of this trait has been analyzed within the latter breed showing large age, season and herd effects. Such an analysis on field data is now completed by studies on the $\mathrm{LH}$ content and ovulation rate of animals from an experimental herd of cows selected on their twinning ability. The natural between-breed variation of this trait seems to be directly related to their ovarian sensitivity to PMS. These results have been observed on contemporary double muscle animals from different beef breeds (Carmaux experimental herd-I44).

In such a research field we are concerned with studies in other disciplins (physiology, nutrition, pathology) to analyze the mechanisms underlying the relations and chiefly the antagonisms between genotypic contributions of calf and dam. These antagonisms which explain the genetic homeostasis of breeds should be particularly well explored when developing crossbreeding schemes between extreme biological types and, furthermore, when considering a practical use of ova transfer technics.

\subsection{3. - Adaptability}

It is more and more clear that beef enterprises will often make profit through the use of marginal lands and by products of crops using their own female calves and those in excess from the dairy herd for replacement. Contrary to the dairy situation, this leads to the use of a wide variety of breeding types in a large scale of environments. This is to stress the importance of studies on the adaptability of animals to fixed and random effects of environmental components: nutritional, pathological, climatic and behavioural.

Several experiments run in Sardinia and in the Central part of France showed that under an extensive management, local hardy breeds expressed a more efficient overall maternal value than beef or dual purpose breeds. If the use of first crosses: beef $\times$ hardy, generally results in a higher weaning weight than that of pure hardy calves, this advantages is reduced when the feed allowance of dams is lowered (higher stocking rate for example). It completely disappears when hardy beef cows are managed under the traditional raising system involving a partial milking ( 165$)$ : only the residual milk being available for calves which are reared apart of cows. In another experiment where dairy, dual purpose and beef cows were raised in a dairy system we have stressed the very low ability of beef animals (Charolais) for milking (cows) and artificial feeding (calves).

During the postweaning phase, differences in the relative growth rate and food conversion of dairy (Friesian), hardy (Salers) and beef (Charolaise, Limousine) bulls and steers fed at different energy levels have been analyzed; the efficiency of fattening young bulls appeared more favourable under intensive systems (BERAN- 
GER, personal communication). Variations have also been observed in the relative ability of Charolaise, Blonde d'Aquitaine and dairy bulls to grow on grass and pelleted feeds.

Research work is in progress to find simple tests expressing directly the adaptability of animals to a specific stress or to a combination of stresses which characterizes a harsh environment. The monthly variation of weight and that of rectal temperature are explored in relation to the adaptation of beef cows to a low feed allowance and high temperatures in the Mediterranean area (Sardinia). More recently the between-breed variation of heat tolerance has been recorded (test of ro hours in a climatic chamber) on 500 animals of the same age (I4 months). Hardy breeds and breeds located in Southern France are generally more tolerant than Northern beef and dairy types. Some differences also occur in the way of transferring heat during the stress period: sweating panting (etc.). The value of such tests has to be checked in field trials conducted in tropical or subtropical environment.

\section{3. - Breeding improvement}

\section{I. - Practical breeding schemes}

The situation of beef cattle breeding was the following when research work began in this field in France:

- existence of powerful breeding societies promoting their breeding stock

- spreading of AI in dairy and commercial beef herds chiefly for commercial crossing.

The first goal of research workers was to establish breeding schemes which could operate efficiently through breeding societies and AI centers:

I) for terminal crossing in dairy or beef herds (breeding for growth traits and direct effects of genes)

2) for purebreeding in our large population of beef cows (I.5 million).

\section{II. - Terminal crossing ( $\mathrm{I} 8 \mathrm{I}$ to $\mathrm{I} 96$ )}

It was clear at the beginning and from previous studies on the genetic variability that these two types of goals were largely conflicting (see above). After some field trials devoted to finding simple recording systems of live weight on farms (direct and indirect estimations through live measurements) (I2I, I22, I25, I26) and of carcass value (estimation of fleshiness through live and carcass assessments, I23, I24), it appeared that the most efficient way of increasing beef production from breeding methods was to select sires for terminal crossing and to expand their semen through AI in the Southern and Central part of France where this type of crossing was developing. Further, AI centers in this area proved to be more receptive than breeding societies to the use of objective breeding methods.

The selection scheme of AI beef bulls for terminal crossing developed progressively from I957 to I970 in successive steps which were not logical but imposed by the official regulation.

I957-I965: Progeny testing of $A I$ bulls for veal production (the most important 
production); a progeny test index was first developed to classify samples of bulls whose progeny was recorded in the same area at the same period (I85). It was designed for the growth rate and conformation score. This index has been progressively modified to fit new situations:

- the necessary limitation of calving difficulties closely related to the direct effect of sires on the birth weight of their progeny calves (I88),

- the correction of genetic differences between years and breeding units through the use of a national control group of sires (I92, I94),

- the evolution of a progeny test on veal production in farms to a progeny test on young bull production in stations,

- the possible use of BLUP procedures (207).

I963-I970: Performance testing of young bulls. This was done on a pelleted diet (alfalfa and barley) animals being fed ad libitum for some breeds, restricted for others (Charolaise) to avoid defects of legs. If performance testing was done after normal weaning time (6-7 months), this restriction limited the in fluence of variation in the milk production of dams on the following growth rate of their calves. This was particularly important with double muscle animals (Carmaux).

The performance test index gives the same statistical weight to conformation score, growth rate and feed efficiency (expressed independently of growth rate and weight).

I966 and there after: Organization of contract matings between top progeny tested sires and a nucleus of beef cows to completely integrate the scheme from one generation to the next. At this stage several ways of producing young sires are compared:

- normal purebred beef animals,

- normal crossbred beef animals,

- D.M. crossbred animals (INRA experimental farm of Carmaux). The production of crossbred sires aims at exploiting the benefit of heterosis on traits like sexual precocity which is delayed with increased muscling and at associating the growth potential of breeds like Charolaise and Maine-Aniou with the longbodied shape and lower birth weight of others (Blonde d'Aquitaine, Limousine).

Procedures have been developed to estimate the breeding value of sires at each step of the scheme taking into account the accumulated information obtained during the operation. The realized genetic progress resulting from the application of this scheme has been analyzed according to the incidence of decisions taken at each step described above (I90, I93). Cooperative organizations in charge of managing such schemes need general advice as to the most efficient way to spend their money for livestock improvement (203). Following the procedures used in a former study on the optimization of progeny testing schemes of AI sires for terminal crossing (20I), we have compared different strategies involving performance testing, progeny testing and a combination of both selection methods. It appears that performance testing is sufficient to select bulls for a commercial use, progeny testing being limited to the choice of top sires to produce young sires for the next generation (202). The development of such integrated schemes is now limited on the sire paths (sire-son and sire-daughter) but the possible use of ova transfer technics could be a good opportunity to develop breeding methods taking into consideration the dam paths (205). For a given increase in the inbreeding coefficient and with the actual feasibility of the technics, such a strategy 
can result in a large increase of genetic progress. One is faced here with many risks, those related to the technology and those biologically involved in selecting a specialized sire line whose females selected on traits expressed before puberty will then never calve and express those traits for which their genetic potential is low (reproduction, adaptability).

An important point in developing terminal crossing operations is the choice of cows to be crossed with beef sires according to their age. It appears that the same sire line should not be used on cows and heifers. Theoretical studies for optimizing the sample of cows to be crossed with beef sires in a dairy herd have been done considering the discounted relative profits from milk and meat (206). The advantage of avoiding beef crossing on any heifer is variable according to several parameters among which is the difierence in the overall breeding value for meat production between terminal sire lines to be used on cows and those to be used on heifers. Following this result, experimental work was done (Union Auvergne-Limousin) to select a small sire line suitable for crossing on heifers (chiefly the dairy heifers).

\section{I2. - Schemes for reproductive traits (I97 to 200)}

In the purebreeding area, chiefly with Charolais, after previous studies on the variation of growth rate before weaning it appeared necessary to give more consideration to fitness traits (fertility, calving and maternal ability). Such traits were not selected in small French beef herds as they were selected under natural selection in large herds of British breeds (America, Australia, South Africa). The breeding improvement of such maternal traits involved progeny testing of bulls. Developing this method to obtain a random sample of female progeny calves and to spread the genetic progress was facilitated in France because of the large development of AI, mainly in the Limousin and Blonde d'Aquitaine areas. The breeding schemes now operating for 5-Io years involve the following steps:

r) Sampling of top dams at 6 years on their numerical efficiency and on their index concerning the weaning weight and weaning conformation score of their progeny calves (mothering ability). They are promoted for AI and bred with semen from the top progeny tested sires.

2) Selection of male calves thus obtained on their preweaning growth rate and conformation, animals with the heaviest birth weight being discarded.

3) Performance testing of these male calves including traits in addition to those considered in the terminal crossing scheme such as pelvic measurements which proved to be useful for the culling of extreme young bulls which will transmit poor calving ability to their progeny calves.

4) Progeny recording: around I50 progeny calves are produced at random from each young bull; this number is required to estimate in field conditions the frequency of calving risks and hereditary defects with low penetrance (arthrogryposis for example).

5) Progeny testing: 20 heifer progeny calves are sampled at weaning for each sire. They are fed at a high level at one location and they are all inseminated with the semen of a control bull for a first calving at 2 years. This standard and intensive system, not common in the French beef industry, is supposed to increase the efficiency of the scheme by shortening the generation interval and allowing a larger expression of the genetic variability of traits like calving and mothering ability. 
Standard indexing procedures of beef sires are now in progress. On the other hand, studies on the optimum way of integrating these different selection steps are difficult, due to the uncertainty in the possibilities of partitioning costs and benefits between users of natural service and AI, between pedigree breeders and commercial producers. We are now considering a scheme in which the genetic progress would be spread not only through AI with the top sires bul also through the production of young bulls for natural service by inseminating the elite cows of pedigree breeders with semen from these top sires.

Like for the terminal crossing scheme, INRA is selecting sires on specific goals and using more sophisticated procedures. It is done in two directions:

I) Breeding scheme for twinning ability in an open herd of Charolais and Maine Anjou cows: we plan to use early indirect measurements of twinning ability and ova transfer technics in order to increase the efficiency of the scheme (145).

2) Breeding for a synthetic beef breed, crossing top sires and dams from the purebred beef schemes. These projects are underway in the experimental farms of Le Pin-au-Haras and La Minière.

\section{2. - Crossbreeding systems (208 to $2 \mathrm{r} 2)$}

Many facts and figures (see above) support a larger and more efficient use of crossbreeding in the beef industry (Crossing is now practical limited in France to terminal crossing):

- the incompatibilities and genetic antagonisms between the direct and maternal effects of genes acting on the overall efficiency.

- the hybrid vigor resulting from both direct and maternal effects of genes.

- the genotype $\times$ environment interaction which can be exploited best when locating each breeding type of a crossbreeding scheme (calf and dam being or not separated) in its optimal environment;

- the age effects on some maternal influences (calving and maternal ability) which could lead to choose the sire breed for each dam according to her age (complementarity). On the other hand, the large variation of cattle breeds in size and muscling and the large expansion of AI in beef herds are creating favourable conditions for the use of crossbreeding systems. Conversely, the small size of herds and the lack of organization of the beef industry are real limiting factors in this process.

Several studies have been completed on this subject or are now in progress, using the experimental facilities available after I967 (Le Pin, Bourges, Carmaux), all of them being devoted to the comparison of crossbreeding systems starting from our dairy, dual purpose, hardy or beef cow populations. They are summarrised in Table 2 and figure $I$ gives the locations on the French area.

Concerning the dairy herds, several strategies are compared (Le Pin au Haras) starting from the most widespread French dual-purpose breed: the Normande:

- grading up to Holstein (U.S. or Canadian);

- criss crossing with Holstein;

- selection for or against milk (using the best and the worst indexed sires from the French national AI dairy scheme). 
B. VISSAC

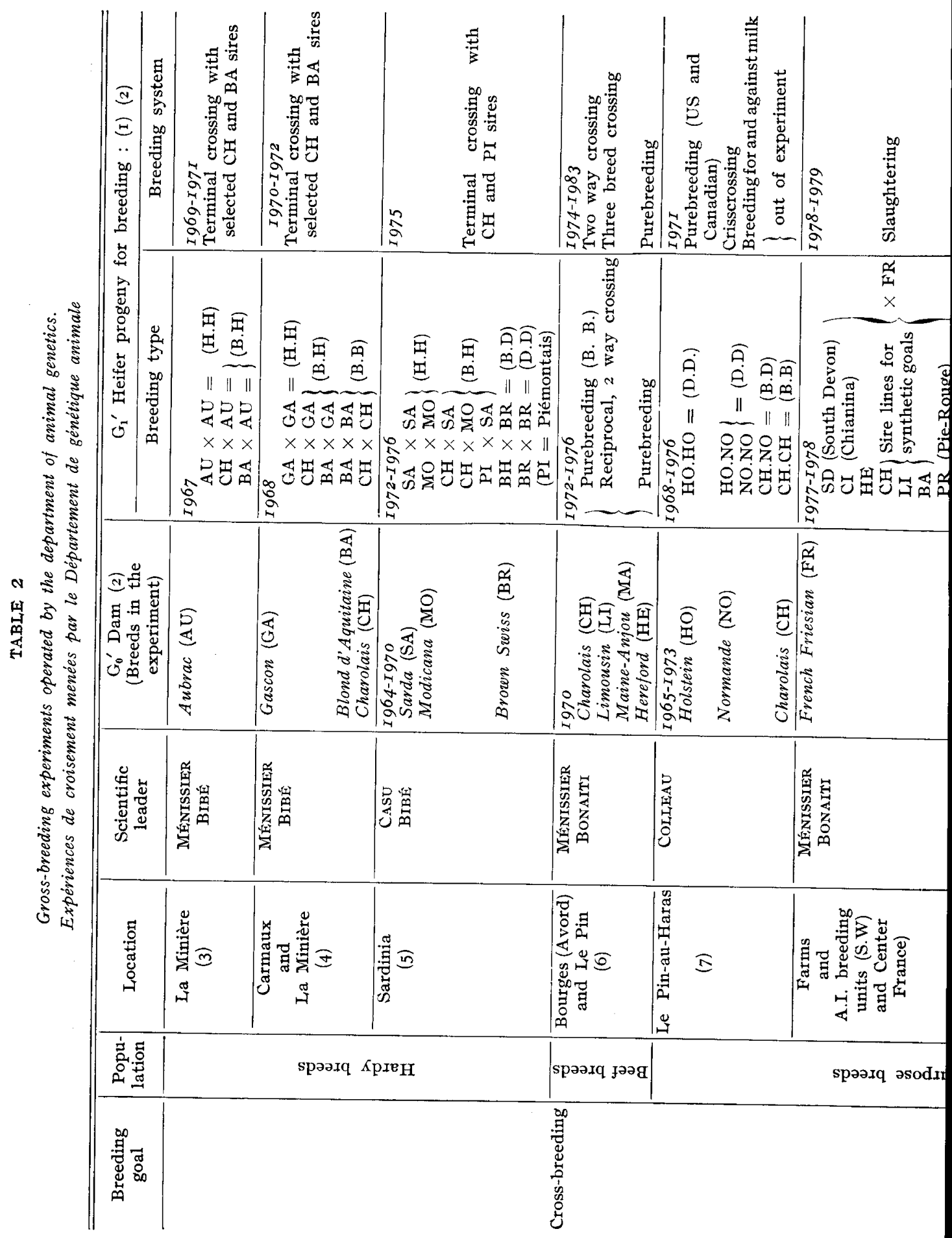




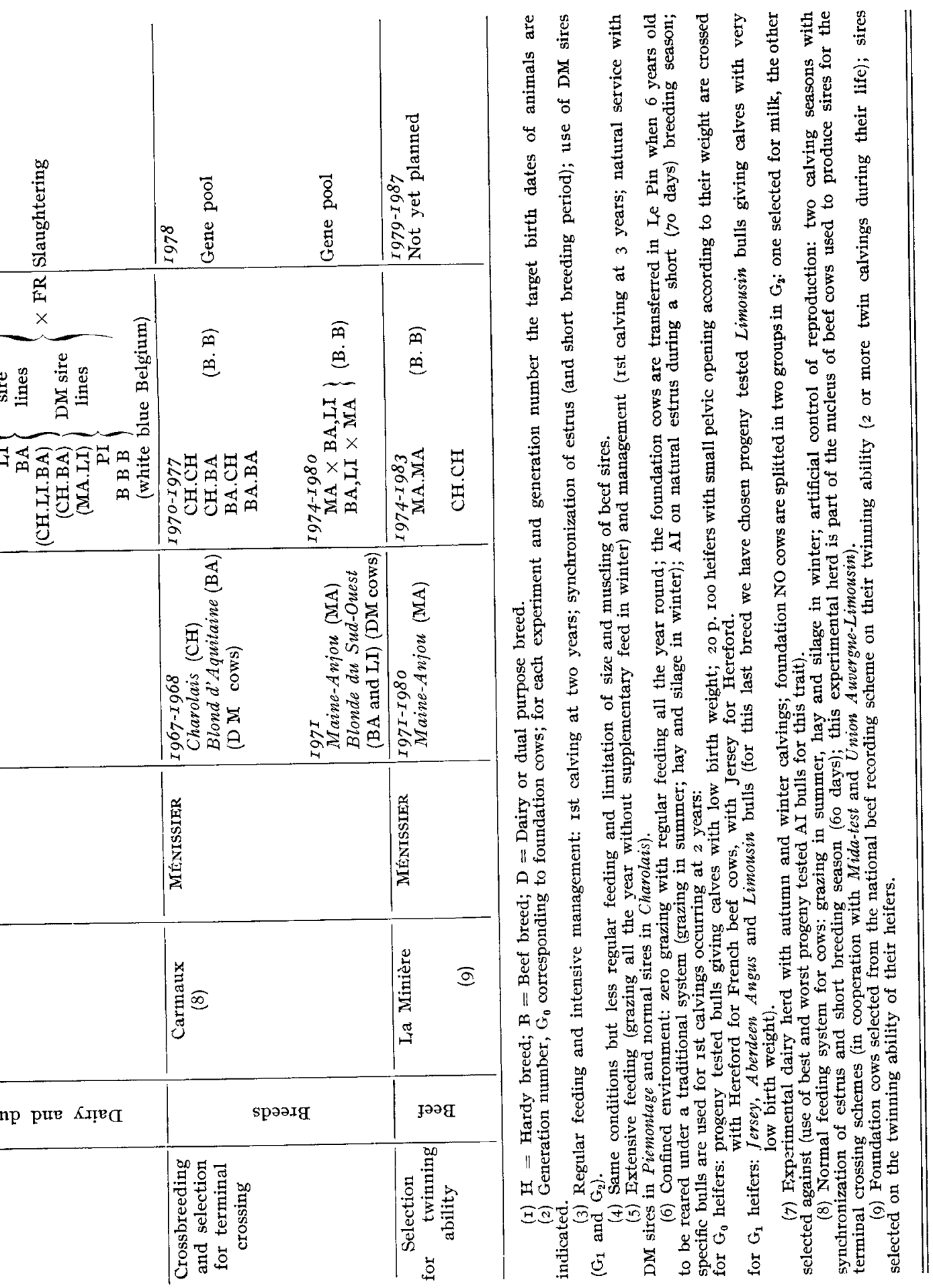


The use of Charolais crossing is also considered in these comparisons.

Using financial supports from EEC, a large field experiment involving crosses between Friesian cows and sires from 17 paternal breeds, breeding types or strains from France or other Western countries is now in progress. Considering the variation between paternal breeds and strains in their sexuality and rate of maturity

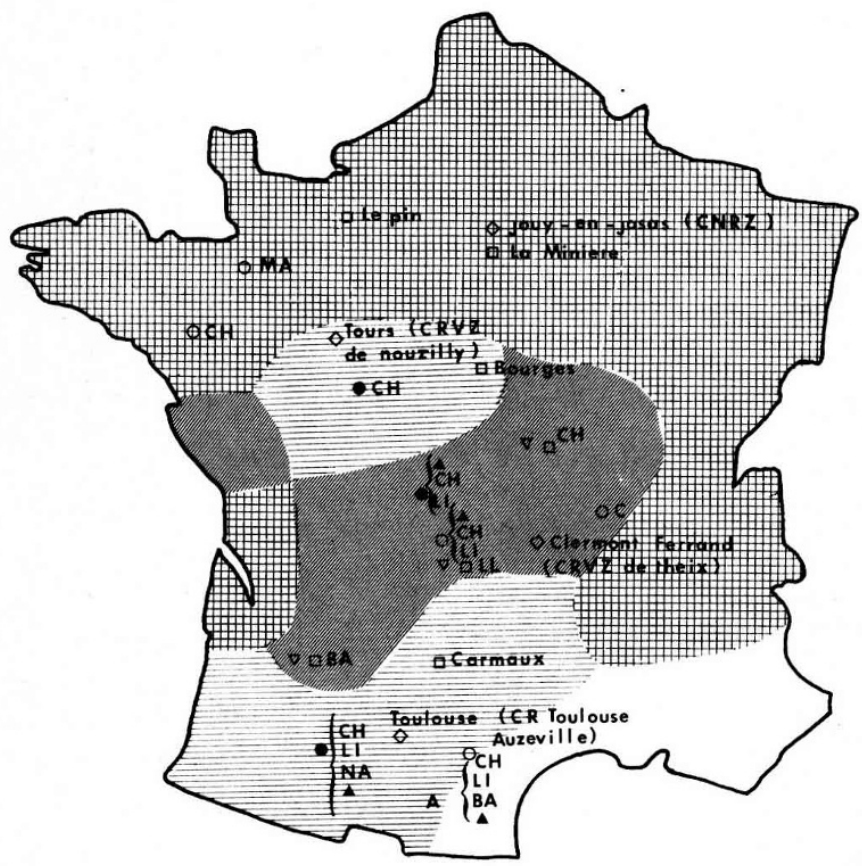

FIG. I. - Location of research laboratories, experimental facilities and testing stations (Beef cattle breeding)

Localisation des laboratoires de recherche, des possibilités expérimentales et des stations de testage pour les bovins à viande

Dominant production systems

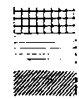

Dairy herds (purebreeding)

Dairy herds (beef crossing)

Beef herds

$\triangle$ Research centers (3)

$\square$ Cattle experimental herds (I)

O Performance test stations (2)

- Progeny test stations (fattening traits of male calves) (2)

* Progeny test stations (fertility and maternal traits of female calves) (2) TOURS -(CRVZ de Nouzilly) and CLERMONT-FERRAND (CRZV de Theix) represent research centers interested by research on beef in other scientific disciplins.

(I) All experimental male calves and culled cows of experimental breeding herds are fattened in I a Minière and slaughtered in the experimental abattoirs of Theix and Jouy-en-Josas.

(2) Only testing stations involved in the beef breeding schemes are given; breeds are indicated for each of them in an abbreviated form: Maine-Anjou (MA), Charolaise (CY), Limousine (L,I), Blonde d'Aquitaine (BA), specialized synthetic line (X).

(3) The national computing center (CTI) where data are processed form the national beef recording scheme is also located in the research center of Jouy-en-Josas. 
progeny calves will be compared at two slaughter ages for male calves, under two management systems for female calves: those from the largest muscular breeding types (the so-called terminal crossing types), chiefly the double muscle strains, will be used as once bred heifers (Ist calving at two years), the other ones will be used as beef cows.

The beef crossbreeding experiment of Bourges has put foward several interesting and practical results:

- the superiority of Limousine as a maternal or paternal breed in the confined environment which was used (zero grazing and partial estrus control);

- the good reciprocal complementarity between the Maine-Anjou and Limousine breeds not crossed anywhere before this experiment. Starting from the results of this experiment and from field data, calculations have been done to fit the right paternal breed on each breed and age of dam for a fixed risk of calving difficulties. This type of approach seems to be essential, the main limitation of beef potential using large sized beef breeds in intensive systems (including the dairy one) being more and more the calving ability of cows (I55-I56).

From studies on local breeds (I73-209-2II) used in extensive range lands of Southern France or Sardinia it clearly appears that terminal crossing (in the harsch environments) and two-step crossing (in the improved ones) with several beef breeds are the most efficient crossbreeding schemes at the commercial level. In the same range conditions (Sardinia), the local dams perform better than the dual purpose (European Brown Swiss) coming from the dairy farms located in the lowlands. Increasing the muscling from the local breeds by crossing with beef bulls is limited by the low sexuality of extreme double muscle beef sires in natural service (usual mating system in range conditions). Further, the adaptability and fertility of $F_{1}$ beef cows from double muscle sires (after AI in the lowlands) are strongly depressed in the extensive areas.

\section{3. - Optimum use of vegetable land resources}

In fact, all crossbreeding experiments show a trend forward the adaptation of breeds in beef herds according to the nutritional level: from the dairy types adapted to the highest level (regular feeding on a yearly cycle), to the beef types for the intermediate level (no supplement in summertime under continental climatic conditions) and to the extreme hardy types (no concentrate, no wintering under Mediterranean climate).

The beef industry being more and more efficient only by converting into meat, vegetable resources from marginal lands and agricultural or industrial by products, on is faced with the general situation of finding optimum low-cost conversion systems. They involve a transfer of nutrients taking into account:

- the seasonal and geographical variation of plant resources

- the fluctuation of nutritional requirements with the physiological status of cattle.

Beside the classical ways of realizing this transfer:

- storing and (or) transferring food from different places to feed the cattle; 
- moving the cattle between areas under different geographical and climatic conditions: Highlands and Lowlands, Alpine and Mediterranean for the coordination of supply and feeding locations;

Animal breeding can play a major and efficient role in this context. Two ways of transferring food to cattle can be considered using benefit from the genetic variation;

- the natural adaptation which occurs in some breeding types (breeds from Corsica) where animals develop habits (moving-feeding) to find by themselves available resources: some stable equilibrium of natural ecosystems can be obtained in this process which is close to that of wildlife.

- the transfer of " cattle genes" by locating the breeding type according to the level of shortage. This principle can be integrated in crossbreeding schemes starting from dairy typed cows (in intensive environments) or hardy typed ones (in harsh environments) both being crossed with beef sires to produce $F_{1}$ cows for intermediate environments.

In this field, research workers have to cooperate with those from other biological disciplins to evaluate beef production systems using local breeds and populations already adapted to harsh environments. This genetic material is now disappearing with the intensification of cattle production which has promoted the most productive animals in the richest areas and has led to the desertion of the other zones. This is probably the most acceptable and efficient way for the society to preserve most of the rare breeds (I979).

French research workers in beef cattle breeding are therefore cooperating with others in biology and human sciences in different marginal areas where local breeds could help to find low cost beef production systems using disappearing local breeds. A pilot interdisciplinary study has been conducted in this way I5 years ago in Aubrac: South Massif Central (I68). We are more recently considering the following situations:

I) the grazing Highlands of the " Pyrénées " (Gasconne breed),

2) the intensive pine florest of the "Landes " under oceanic climatic conditions (Bazadaise breed),

3) the Mediterranean dry areas (South Eastern France and Corsica).

In the last two cases, beef production has to be considered as part of a joint industry involving wood production (item 2) and touristic activities (item 3). The prevention against fire spreading which is more and more important for these productions and activities, can be obtained more efficiently than with machines if cattle are allowed to clean the forest. A similar kind of approach is considered in a research project conducted in the Northern part of the Ivory Coast: the overall relationships between plant, cattle and local populations are descrited before going further in studying breeding improvement procedures of animals.

\section{4. - Conclusion}

Beside its scientific originality, the variability of the genetic material and environments involved which may interest many European countries, the French research work on beef cattle breeding may have several other accomplishments 
Beef cattle breeding was first developed through strong connections with breeding organizations, field operations preceding more artificial testing procedures then experimental work. Although this perhaps limits the actual statement of scientific results it has however a favourable influence on the practical efficiency of research work for the beef industry.

Due to the large extension of AI, breeding methods have been established using similar procedures to those developed by dairy cattle breeding units. They can help to foreward the breeding improvement of beef cattle in most countries where AI is developing.

The most interesting result of field and experimental works has been to stress the genetic antagonisms which exist between the direct and maternal effects of genes, the first ones being chiefly expressed in the size and muscling, the other ones in the fitness traits. These antagonisms occur between breeds as well as within breeds. Their analysis for each trait like calving ability, mothering ability and fertility seems to be an efficient way of finding optimal combinations between paternal and maternal breeds: such studies have to take into account the fact that most of these traits are determined by threshold effects resulting from an equilibrium between the calf and dam genotypes.

The understanding of such characteristics of the genetic variation in beef herds can be made easier by a full description of chromosomal or other polymorphisms which occur locally in beef breeds, most of them being probably related at the same time to the muscling and to the components of fitness.

The dairy industry being more and more devoted to intensive and artificial environments, beef cattle breeding is particularly faced with the general problem of maintaining the genetic variability of cattle; this problem is a part of the more and more urgent need for developping low-cost feeding and management systems: marginal lands now abandoned but formerly used by local breeds often represent the main plant resources for cattle in such systems. French research work in animal breeding is engaged here in interdisciplinary works concerning continental and mediterranean marginal lands where beef production is connected with wood production, land preservation and touristic activities.

\section{5. - References}

\section{1st part: Polymorphisms}

$$
\text { A. - CHROMOSOMES }
$$

\section{I. - General studies:}

(I) PoPescu C. P., I97I. Observations cytogénétiques chez Bos taurus $L$. Thèse de doctorat d'État, Orsay, I35 p.

(2) Cribiv E. P., I974. Observations sur les chromosomes somatiques chez Bos taurus L. Thèse de doctorat de $3^{\mathrm{e}}$ cycle, Paris VI, $5^{\circ} \mathrm{p}$.

(3) Popescu C. P., I976. Observations sur le caryotype normal et anormal des bovins. II ${ }^{e}$ Colloque sur la reproduction animale, $27-28$ avril 1976 , Saint-Hyacinthe, Québec, Canada. Canad. Vet. J., 18, I43-149. 
2. - Technical papers :

(4) Popescu C. P., I973. L'hétérochromatine constitutive dans le caryotype bovin normal et anormal. Ann. Génét., 16, 183-188.

(5) Popescu C. P., I974. Étude du caryotype bovin par une nouvelle méthode cytogénétique : les bandes C. I er Congr. Mond. Génét. appl. Élev., Madrid, 3, r 59-164.

(6) POPESCU C. P., 1975. Essai d'identification des chromosomes bovins à l'aide du marquage au 5-bromodéoxyuridine (BUDR). $2^{\mathrm{e}}$ Coll. europ. Cytogénét. anim. domest., Giessen, 59-64.

(7) POPESCu C. P., 1975. L'étude du caryotype bovin par la méthode des bandes. Colloque DGRST, "Biologie de la procréation ", Ann. Biol. anim., Bioch., Biophys., 15, 751-756.

3. - Normal chromosomes:

(8) Popescu C. P., r969. The idiograms of the yak, the cattle and their hybrid. Ann. Génét. Sél. anim., 1, 207-2 I7.

(9) Popescu C. P., 1970. Le rapport $X /$ autosomes chez quelques espèces de mammifères

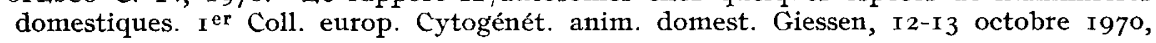
101-107.

(ro) Popescu C. P., 197r. Les chromosomes méïotiques du bœuf (Bos taurus). Ann. Génét Sél. anim., 3, I25-143.

(iI) Cribiu C. P., Popescu C. P., I974. L’idiogramme de Bos taurus L. Ann. Génét. Sél. anim., 6, 29I-296.

\section{4. - Descriptions of abnormal chromosomes:}

(I2) Popescu C. P., 197I. Deux cas nouveaux de fusion centrique chez les bovins. Ann, Génét. Sél. anim., 3, 521-525.

(13) Froget J., Coulon J., Nain M. C., Dalbiez J. M., I972. Anomalie chromosomique de type fusion centrique chez un veau charolais. Bull. Soc. Sci.Vét. Med.comp., Lyon, 74, I3I-I 35 .

(14) Popescu C. P., i972. Un cas possible d'inversion péricentrique chez les bovins. Ann. Génét., 15, 197-199.

(I5) POPEscu C. P., I973. Nouvelles observations sur une fusion centrique chez Bos taurus. Ann. Génét. Sél. anim., 5, 435-440.

(16) POPESCU C. P., I973. Observations sur les spermatocytes primaires des taureaux hétérozygotes pour une fusion centrique. Colloque de 1'Institut national de la Santé et de la Recherche médicale, "Les accidents chromosomiques de la reproduction ", Paris, I89-I94.

(i7) Cribiu E. P., Popescu C. P., i974. Un cas de chromosome Y anormalement long chez Bos taurus L. Ann. Génét. Sél. anim., 6, 387-390.

(18) Darre R., Berland H. M., QueinNeC G., I974. Une nouvelle translocation robertsonienne chez les bovins. Ann. Génét. Sél. anim., 6, 297-303.

(I9) CRIBIU E. P., I975. Variation interraciale de la taille du chromosome $\mathrm{Y}$ chez Bos taurus. Ann. Génét. Sél. anim., 7, 139-144.

(20) Popescu C. P., Cribiu E. P., Tschudi P., i975. Deux cas de fusion centrique chez Bos taurus L. en Suisse. Ann. Génét. Sél. anim., 7, 317-319.

5. - Studies on populations:

(2I) Darre R., QUeINNEC G., BerLAND H. M., I972. La translocation $\mathrm{r} / 29$ des bovins. Étude générale et importance du phénomène dans le Sud-Ouest. Rev. Méd. vét., 123, 477-494.

(22) POPESCU C. P., r974. Observations sur une fusion centrique chez les bovins (Bos taurus L.) rer Congr. Mondial. de Génét. appl. Élev., Madrid, octobre, 3, I65-168.

(23) Cribiu E. P., Popescu C. P., 1975. Sur la fréquence des chimérismes leucocytaires $\mathrm{XX} / \mathrm{XY}$ parmi les taureaux d'insémination. $2^{\mathrm{e}}$ Coll. europ. Cytogénét. anim. domest., Giessen, 204-2Ir. 
(24) DE Giovanni A., Popescu C. P., Succi G., I975. Première étude cytogénétique dans un centre italien d'insémination artificielle. Ann. Génét. Sél. anim., 7, 31 I-3I5.

(25) Popescu C. P., I975. Sur la fréquence de la translocation $1 / 29$ dans certaines races bovines. $2^{\mathrm{e}}$ Coll. europ. Cytogénét. anim. domest., Giessen, 277-282.

(26) Popescu C. P., I976. Sister chromatid exchanges (S.C.E.) in normal and abnormal bovine (Bos taurus L.) caryotype (sous presse). Covayokegia (Tokio).

(27) Popescu C. P., 1976. New data on pericentric inversion in cattle (Bos taurus). Ann. Génét. Sél. anim., 8, 443-448.

\section{B. - BIOCHEMICAL POLYMORPHISMS}

I. Blood groups:

(28) Grosclaude F., Milıot P., I962. Contribution à l'étude des groupes sanguins de la race bovine Montbéliarde. - Observation sur la structure génétique de la race dans une zone d'insémination artificielle. Ann. Biol. anim. Bioch., Biophys., 2, I85-208.

(29) Grosclaude F., Millot P., r963. Allèles supplémentaires au locus $\mathrm{S}$ de groupes sanguins de bovins. Ann. Biol. anim., Bioch., Biophys., 3, I I9-I24.

(30) Grosclaude F., Ol.rivier L., I963. Note sur une estimation de fréquence génique dans une étude sur les groupes sanguins. Ann. Biol. anim. Bioch. Biophys., 3, 427-432.

(3I) Grosclaude F., I963. Allèles du locus $\mathrm{S}$ de groupes sanguins des bovins. Nouveaux résultats. Ann. Biol. anim. Bioch. Biophys., 3, 433-435.

(32) Grosclaude F., I964. Applications des groupes sanguins dans l'étude de la génétique des populations. Rapport des journées d'étude des groupes sanguins. École vétérinaire de Gand, 7 I-87.

(33) Grosclaude F., r965. Note préliminaire sur un locus supplémentaire de groupes sanguins des bovins, le locus T'. Ann. Biol. anim. Bioch. Biophys., 5, 403-405.

(34) Grosclaude F., I965. Mise au point sur le locus $S$ des groupes sanguins des bovins. Immunogenetics Letter, 4, 93-94.

(35) GrosclaUdE F., I965. Studies on the $S$ blood-group system in French cattle breeds. In Blood Groups of Animals. Proc. 9th Europ. anim. blood group Conf., Prague, the Czechoslovak Acad. Sci., 79-85.

(36) GroscraUde F., r966. Phénogroupes du locus B dans les races bovines françaises. État actuel (liste ronéotypée).

(37) Grosclaude F., r966. Note sur le mode d'hérédité d'uu nouveau facteur de groupes sanguins des bovins. Immunogenetics letter, 4, I 7 r-I 72 .

(38) BoUQUeT Y., GROSClaUdE F., r968. Groupes sanguins et variabilité génétique comparée dans les races Flamande et F.F.P.N. Ann. Biol. anim., Bioch., Biophys., 8, 463-483.

2. - Antigens of white cells and saliva:

(39) Wroblewski A., Podliachouk L., Millo' P., 1958. Recherche de mutants de groupes sanguins dans le sérum et la salive des bovins. Ann. Inst. Pasteur, 94, 456.

(40) Mrr, OT P., I964. Importance of antiglobulin reaction for detection of new factors in cattle. Proc. 9th Europ. Anim. Blood Group Conf., Prague, the Czechoslovak Acad. Sci., 449.

(4I) MILLO'T P., I966. Détermination d'iso-antigènes thrombocytaires chez les bovins. $C . R$. Acad. Sci., Paris, 262 D, 1918-1920.

(42) Mirlot P., I967. Grouges thrombocytaires chez les bovins. In polymorphismes biochimiques des animaux, I.N.R.A., Institut Pasteur, 1, I 29-I32.

(43) MILLOT P., I967. Les réactions d'agglutination hétéro-et iso-antiglobuliniques des bovins. In polymorphismes biochimiques des animaux. I.N.R.A., Institut Pasteur, 1, 47 I-475.

(44) Mrrzo' P., r969. Les groupes sériques d'inhibition chez les bovins. C. R. Acad. Sci., Paris, $269 D, 2053-2055$.

(45) Mrı́ot P., r969. Étude chez les bovins de trois facteurs sériques d'inhibition génétiquement transmis. C. R. Acad. Sci,. Paris, 269 D, 2 I 53-2 I55.

(46) Mirzot P., r97o. Les groupes sériques d'inhibition de 1'agglutination iso-antiglobulinique chez les bovins. I. Étude immunologique. Ann. Inst. Pasteur, 119, 590-620. 
(47) MirLot P., I971. Les groupes sériques d'inhibition de l'agglutination iso-antiglobulinique chez les bovins. II. Étude de la transmission génétique de trois facteurs : iA, iB, iC. Ann. Inst. Pasteur, 120, 739-750.

(48) MILLOT P., I972. The inhibition groups in the sera of cattle. Proc. I2th europ. Conf. Anim. Blood Groups Biochem. Polymorph. Acad. Sci., Hongrie, Budapest, 1, I2I-I 24.

3. - Antigens of spermatozoa:

(49) Prakash C., 1973. Les alloantigènes sur les spermatozoïdes de mammifères. Déterminisme de ces antigènes par le génome haploïde des spermatozoïdes. Ann. Génét. Sél. anim., $5,507-5$ I 8 .

(50) Prakash C., I974. Mise en évidence sur les spermatozoïdes bovins de quelques antigènes appartenant au système de groupes sanguins $S$. Ann. Génét. Sél. anim., 6, I-I6.

(5) Prakash C., I974. Séparation des spermatozoïdes mobiles des autres cellules et des débris cellulaires présents dans le sperme bovin. Ann. Biol. anim. Bioch., Biophys., 14, 363-369.

(52) Praskash C., I974. Absence d'anticorps spécifiques des groupes sanguins chez les bovins immunisés à l'aide de spermatozoïdes de taureaux. Ann. Génét. Sél. anim., 6, 497-50o.

4. - Milk proteins:

(53) Grosclaude F., Garnier J., Ribadeau-Dumas B., Jeunet R., ig64. Étroite dépendance des loci contrôlant le polymorphisme des caséines $\alpha_{s}$ et $\beta$. C. R. Acad. Sci., Paris, 259, I 569 - 157 I.

(54) Grosclaude F., Pujolle J., Garnier J., Ribadeau-Dumas B., i965. Déterminisme génétique des caséines $x$ du lait de vache; étroite liaison du locus $x-C n$ avec les loci $\alpha_{s-C n}$ et $\beta-C n$. C. R. Acad. Sci., Paris, 261, 5229-5232.

(55) Grosclaude F., Pujolle J., Garnier J., Ribadeau-Dumas B., ig66. Mise en évidence de deux variants supplémentaires des protéines du lait de vache : $\alpha_{s_{1}}-C n D$ et $L g D$. Ann. Biol. anim., Bioch., Biophys., 6, 215-222.

(56) Grosclaude F., Pujolle J., Ribadeau-Dumas B., Garnier J., ig66. Analyse génétique du groupe de loci de structure synthétisant les caséines bovines. In polymorphismes biochimiques des animaux, I.N.R.A., Paris, 4I5-420.

(57) Grosclaude F., Mercier J. C., Ribadeat-Dumas B., i969. Sur la localisation dans 1a séquence COOH-terminale de la caséine $\alpha_{s_{1}}$ bovine, de la substitution Glu/Gly différenciant les variants génétiques $B$ et $C$. C. R. Acad. Sci., Paris, 268, 3133-3136.

(58) Grosclaude F., Mahé M. F., Mercier J. C., Ribadeau-Dumas B., I97o. Localisation dans la partie $N H_{2}$-terminale de la caséine $\alpha_{s_{1}}$ bovine d'une délétion de $1_{3}$ acides aminés différenciant le variant $A$ des variants $B$ et $C$. FEBS Letters, 11, Io9-112.

(59) Ribadeau-Dumas B., Grosclaude F., Mercier J. C., I970. Localisation dans la chaîne peptidique de la caséine $\beta$ bovine de la substitution His/Gin différenciant les variants génétiques $A^{2}$ et $A^{3}$. C. R. Acad. Sci., Paris, 270, 2369-2372.

(6o) Grosclaude F., Mahé M. F., Mrrcier J. C., Ribadiau-Dumas B., i972. Caractérisation des variants génétiques des caséines $\alpha_{s_{1}}$ et $\beta$ tovines. Eur. J. Biochem., 26, 328-337.

(6I) Grosclaude F., Mahf́ M. F., Mercier J. C., Ribadeau-Dumas B., I972. I.ocalisation des substitutions d'acides différenciant les variants $A$ et $B$ de la caséine $\times$ bovine. Ann. Génét. Sél. anim., 4, 515-521.

(62) Grosclaude F., Mercier J. C., Ribadeau-Dumas B., 1973. Genetic aspects of cattle casein research. NIZO/IDF casein symposium 1972. Neth. Milk Dairy J., 27, 328-340.

(63) Grosclaude F., Mahé M. F., Mercier J. C., i974. Comparaison du polymorphisme. génétique des lactoprotéines du zébu et des bovins. Ann. Génét. Sél. anim., 6, 305-329

(64) Grosclaude F., Mahś M. F., Voglino G. F., I974. Le variant $\beta E$ et le code de phisphorylation des caséines bovines, FEBS Letters, 45, 3-5.

(65) Grosclaude F., I974. Analyse génétique et biochimique du polymorphisme électrophorétique des caséines $\alpha_{s_{1}}, \beta$ et $x$ chez les bovins (Bos taurus) et les zébus (Bos indicus). Thèse de doctorat ès sciences, Université de Paris-VII. 


\section{C. - COAT COLOUR}

I. - Historical papers:

(66) DE LAPPARENT, I9I4. Étude sur les races, variétés et croisements de l'espèce bovine en France. Paris, Imprimerie nationale.

(67) QUirTtET E., I963. Les races bovines françaises. Collection "Les races d'animaux domestiques ". La maison rustique, Paris, $7^{8} \mathrm{p}$.

\section{2. - General papers:}

(68) LAUVERgne J. J., I966. Contribution à l'étude de l'hérédité de la couleur du pelage chez les bovins domestiques. Thèse $3^{\mathrm{e}}$ cycle, Fac. Sci., Paris, $5^{8}$ p.

(69) Lauvergne J. J., Ig66. Génétique de la couleur du pelage des bovins domestiques (Bos taurus L.). Bibliogr. Genet., 20, I-68.

(70) LAUVERGNE J. J., I972. Les mutants mendéliens à effets visibles dans les races bovines françaises. Session de l'Agence pour la coopération technique industrielle et économique sur : "les races bovines pour l'accroissement de la production de viande ", Union nationale des livres généalogiques, Paris, $4 \mathrm{p}$.

(7I) LAUVERGNE J. J., WinZENRIED H. U., 197z. Les mutants géniques à effets visibles dans les races bovines de Suisse. Ann. Génét. Sél. anim., 4, 523-535.

(72) LAUVERGNE J. J., I972. Utilisation consciente et inconsciente de certains facteurs mendéliens dans la sélection des grosses espèces domestiques. Ann. Génét. Sél. anim., 4, 79-85.

(73) Succi G., IAUVVERGNE J. J., 1973. Les mutants géniques à effets visibles dans les races bovines d'Italie. Ann. Génét. Sél. anim., 5, 299-31z.

(74) WINZENRIED H. U., LAUVERGNE J. J., I973. Recherches sur les gènes à effets visibles chez les bovins. Schweizer. Arch. Tierheilk., 115, 95-ro5.

\section{3. - Genetic studies:}

(75) LAUVergne J. J., WinzenRied H. U., I969. Déterminisme héréditaire et extension de la ceinture blanche et des flancs colorés en race Brune des Alpes de Suisse. Ann. Génét. Sél. anim., 1, I 76 (abstr.).

(76) LAUVERGNE J. J., I97o. Gonadal hypoplasia and white coat colour in swedish highland cattle. J. Hered., 61, 43-44.

(77) Mrsuraca G., Prota G., Lauvergne J. J., I974. Pigments mélaniques du pelage de quelques races bovines : le schéma possible de certaines actions géniques. Ann. Génét. Sél. anim., 6, 399-404.

\section{D. - HEREDITARY DEFECTS}

\section{I. - General studies:}

(78) Lauvergne J. J., I968. Catalogue des anomalies héréditaires des bovins. Bull. tech. Dépt. Génét. anim., 1, $99 \mathrm{p}$.

\section{2. - Methodology:}

(79) LAUVERGNe J. J., LEFORT G., I973. Nouvelle méthode pour analyser le comportement et la fréquence des gènes récessifs à effets visibles dans les populations bovines .C. R. Acad. Sci., Série D, Paris, 277, 2793-2796.

(80) LAUVERGNe J. J., I974. Étude des gènes à effets visibles à partir des données de testage des taureaux sur leur descendance. I ${ }^{\text {er }}$ Congr. Mond. Génét. appl. Élev., Madrid, 1, 47-55. 
(8I) LEFORT G., LAUVERGNE J. J., I974. L'éradication des gènes récessifs à effets visibles dans les populations bovines où les taureaux sont mis à l'épreuve sur leur descendance. C. R. Acad. Sci., Paris, Série D, 279, I $381-1384$.

\section{3. - Specific studies:}

a) Descriptions of abnomalities:

(82) Florentin P., LAUVERGNe J. J., ig62. Une nouvelle anomalie héréditaire chez les bovins : le caractère "tête de mouton". Rec. Méd. vét., 138, 341-356.

(83) Lauvergne J. J., ig6z. Nouveau cas de polydactylie héréditaire chez les bovins. Ann. Zootech., 11, I $5 \mathrm{I}-\mathrm{I} 56$.

(84) LAUVFRgNe J. J., CuQ P., 1963. Ectromélie et otocéphalie héréditaires en race Française Frisonne Pie Noire. Ann. Zootech., 12, 181-192.

(85) Weber W., Lauvergne J. J., I964. Trois cas d'albinisme rencontrés en Suisse dans la race Brune des Alpes. Ann. Zootech., 13, I5 5 -1 64.

(86) Blin P. C., LAUVERGNe J. J., I967. La probatocéphalie, anomalie héréditaire des bovins dits " tête de mouton ". I. Étude descriptive. Ann. Zootech., 16, 65-88.

(87) LAUVERgne J. J., I967. A propos de l'anomalie héréditaire "bouledogue " en race Française Frisonne Pie Noire. Bull. mens. Soc. vét. prat. Fr., 51, I79-185.

(88) LAUVERgne J. J., Blin P. C., r967. Fissure palatine héréditaire associée à l'ankylose des membres dans la race Charolaise. Ann. Zootech., 16, 291-300.

(89) Lauvergne J. J., Pavaux C., ig69. Hydrocéphalie et cardiopathie héréditaires en race Limousine. Ann. Génét. Sél. anim., 1, Io9-I 7 .

(9o) Denis B., Theret M., Bi,in P. C., Bernard C., Lauvergne J. J., i975. Hypotrichose congénitale en race Normande. I. Étude descriptive. Ann. Génét. Sél. anim., 7, 25I-26I.

b) Genetic analysis:

(9I) IAAUVERGNe J. J., Vissac B., I963. Genetical study of " tête de mouton " cattle. XIth Int. Congr. Genet., 1, 264-265.

(92) LAUVERGNE J. J., Blin P. C., I968. Hereditary determinism of the cleft palate associated with ankylosis of limbs in Charolais cattle. XIJth Int. Conf. Genet., 1, 277.

(93) WinzenRIed H. U., LAUVergne J. J., I968. Albinism among Brown Swiss cattle. XIIth Int. Conf. Genet., 1, 280.

(94) Lauvergne J. J., r970. La probatocéphalie, anomalie héréditaire des bovins dits " tête de mouton ". II. Étude génétique. Ann. Génét. Sél. anim., 2, 363-379.

(95) Weber W., LAUVERgne J. J., Winzenried H. U., i973. Albinisme héréditaire en race Tachetée Rouge de Suisse. Schweizer. Arch. Tierheilk., 115, I42-144.

(96) LAUUVEGNE J. J., WinzenRIED H. U., SUCCI G., 1974. Nouvelles précisions sur 1'albinisme en race Brune des Alpes. ${ }_{I}^{\text {er }}$ Congr. Mond. de Génét. appl. Élev., Madrid, 3, $4 \mathrm{r}-43$.

(97) Winzenried H. U., Lauvergne J. J., I974. Test d'allélisme entre les albinismes de deux races bovines suisses. I er Congr. Mond. Génét. appl. Élev., Madrid, 8, 33-34.

(98) IAAUVERGNE J. J., 1975. État actuel des connaissances sur les syndromes d'arthrogrypose et de palatoschisis (SAP) dans le bétail Charolais en France. Ann. Génét. Sél. anim., 7, $321-330$.

\section{E. - DOUBLE MUSCLING}

1. - General papers:

(99) Vissac B., 1962. Premières recherches françaises sur le caractère culard. Fédération européenne de Zootechnie, Vienne.

(roo) Vissac B., Neuvy A., I96z. Contribution à l'étude du phénomène culard. Union nationale des livres généalogiques, 16 , rue Claude-Bernard, Paris, $52 \mathrm{p}$.

(roi) Latvergane J. J., Vissac B., Perramon A., 1963. Étude du caractère culard. I. Mise au point bibliographique. Ann. Zootech., 12, 133-1 56. 
(I02) VISSAC B., 1966. Document de travail sur les recherches françaises concernant le caractère culard. Féd. Europ. Zootech., Édimbourg.

(го3) Lauvergne J. J., Boyazoglu J. G., Hubert D., i968. Le phénomène culard chez les bovins. Bibliographie annotée. Bull. Techn. Dépt. Génét. anim., 3, 49 p.

(ro4) VISSAC B., I97r. L'hypertrophie musculaire d'origine génétique ou caractère culard. $22^{\mathrm{e}}$ Réunion annu. Féd. Europ. Zootech., Paris-Versailles, I7-19 juillet 1971, $20 \mathrm{p}$.

(I05) MENISSIER F., I974. Hypertrophie musculaire d'origine génétique chez les bovins : description, transmission, emploi pour l'amélioration de la production de viande. $I^{\mathrm{er}}$ Congr. Mond. Génét. appl. Élev., Madrid, 1, 85-107.

2. - Description:

(ro6) Ouhayoun J., Beaumont A., ig68. Étude du caractère culard. III. Anatomie microscopique comparée du tissu musculaire de mâles charolais, normaux et culards. $A n n$. Zootech., 17, 213-223.

(107) VISSAC B., I968. Étude du caractère culard. II. Incidence du caractère culard sur la morphologie générale des bovins. Ann. Zootech., 17, 77-101.

(I08) Ouhayoun J., Arnal. Th., I969. Étude du caractère culard. IV. Anatomie microscopique comparée du rein de mâles Charolais normaux et culards. Ann. Génét. Sél. anim. 1, IOI-IO8.

(I09) Logeay B., VISSAC B., I970. Etude du caractère culard. V. Expérience de croisement entre bovins culards et normaux. Ann. Génét. Sél. anim., 2, 5-17.

(I Io) HALIPRE A., I973. Etude du caractère culard. X. Sensibilité des bovins culards au stress thermique. Ann. Génét. Sél. anim., 5, 441-449.

(i I I) Vissac B., Ménissier F., Perrefau B., i973. Étude du caractère culard. VII. Croissance et musculature des femelles, déséquilibre morphologique au vêlage. Ann. Génét. Sél. anim., 5, 23-58.

(i I 2) Vissac B., Perreau B., Maulíon P., Menissier F., i974. Étude du caractère culard. IX. Fertilité des femelles et aptitude maternelle. Ann. Génét. Sél. anim., 6, 35-48.

\section{3. - Genetic studies:}

(II3) Vissac B., LAUVERGNe J. J., I969. Enquête sur le caractère culard dans la zone charolaise. Ann. Génét. Sél. anim., 1, I77 (abstr.).

(ri4) MÉNISSIER F., BrBé B., r97r. Variations de fréquence du caractère culard dans la descendance de taureaux culards suivant le type génétique des mères : résultats partiels. Ann. Génét. Sél. anim., 4, 126-127 (abstr.).

(II5) McKeliar J. C., Ouhayoun J., I973. Étude du caractère culard. VIII. Fréquence et expression en race South Devon. Ann. Génét. Sél. anim., 5, 163-176.

\section{4. - Use in breeding plans:}

(i 6) Valis Ortiz J. M., Menissier F., Vissac B., i971. Possibilités d'utilisation et de sélection de taureaux culards en vue du croisement de première génération pour la production de veaux de boucherie. Ann. Génét. Sél. anim., 4, 127 (abstr.).

(II7) VAlis OR'TIZ J. M., MENISSIER F., VISSAC B., I972. Etude du caractère culard. VI. Transmission et possibilités d'utilisation en croisement de première génération pour la production de veaux de boucherie. Ann. Génét. Sél. anim., 4, 7-28.

(i 18 ) Bibe B., Frebling J., Gillard P., Menissier F., I974. Incidence de 1'utilisation de taureaux culards sur la production de jeunes bovins à partir de femelles laitières. I. Croissance pondérale, consommation alimentaire et développement corporel jusqu'à l'abattage. II. Performance d'abattage. I r Congr. Mond. Génét. appl. Élev., Madrid, 3, $857-876$.

(I I9) BIBE B., GILLARD P., I974. Incidence de 1'hypertrophie musculaire sur les caractéristiques bouchères de jeunes bovins. I er Congr. Mond. Génét. appl. Élev., Madrid, 3, 73-79.

(i zo) Bibe B., Frebling J., Menissrer F., Vissac B., 1977. Double muscled sires for terminal crossing: French experiments. C.E.C. Seminar : "Crossbreeding experiments and strategy of breed utilisation to increase beef production. Verden, February 9-I I, r976; C.I; C. Eur 5492 E, 72-96. 


\section{2nd part: Polygenic variation}

\section{A. - RESEARCH ON GROWTH CHARACTERS}

\section{I. - Recording procedures:}

(I2I) Del,age J., Poly J., Vissac B., I955. Étude de l'efficacité relative des diverses formules de barymétrie applicables aux bovins. Ann. Zootech., 4, 2 I9-23I.

(I22) Aurior, P., Duplan J. M., I960. Recherches barymétriques sur les veaux de race Charolaise. C. R. Acad. Agr., 46, 938-943.

(123) Rouvier R., VISSAC B., I963. Application of factor analysis methods to the study of morphological variability in carcasses of adult cattle. 5th Int. Biom. Conf., Cambridge, $2 \mathrm{I}$.

(I24) Rouvier R., Vissac B., I964. Application des méthodes d'analyse factorielle à l'étude de la variation morphologique de carcasses de bovins adultes. Biom. Prax., 5, 93-I Ir.

(125) Vissac B., I966. Recherches sur les possibilités d'emploi de la barymétrie chez les bovins. Ann. Zootech., 15, I5-45.

(i 26) Poujardieu B., I969. Recherche d'une méthode d'estimation de 1'aptitude laitière des femelles ovines et bovines pendant la phase d'allaitement. Ann. Zootech., 18, 299-3I6.

2. - Genetic variation (Direct effect of genes) :

a) Veal production (Field data)

(r 27 ) Poly J., Bonelili P., Vissac B., Salone B., r964. Confronto biometrico tra la razza bovine utilizzabili in Sardegna nell' incrocio industriale per la produzione della carne. Zootech. Vet., 19, 65-86.

(128) Vissac B., Frebling J., Faucon A., I965. Statistiques générales sur la production des veaux en croisement industriel dans le Centre et le Sud-Ouest de la France. Bull. Tech. Int., 204, 889-939.

(I 29) Belic M., MENissien F., 1968. Étude de quelques facteurs influençant les difficultés de vêlage en croisement industriel. Ann. Zootech., 17, I07-142.

(izo) Poujardieu B., Vissac B., ig68. Étude biométrique de la valeur bouchère de veaux croisés Charolais et Limousins. I. Paramètres génétiques et phénotypiques. Ann. Zootech., 17, I43-I 58 .

(I3I) Santa Coroma M., Mocquó J. C., I97r. Étude biométrique de la valeur bouchère des veaux croisés Charolais et Limousins. II. Variabilité génétique des index suivant les élevages d'origine et les lignées paternelles. Ann. Génét. Sél. anim., 3, I87-200.

(132) Vissac B., Bonhomme D., Frebling J., I97I. L'utilisation des races à viande françaises en croisement de première génération pour la production de veaux de boucherie. Bull. tech. Dépt. Génét. anim., 12, 27 p.

(I33) Bonhomme D., Foulley J. L., I974. Facteurs de variation de l'hématocrite des bovins. III. Analyse de la variabilité génétique et phénotypique en croisement industriel. Ann. Génét. Sél. anim., 6, 49-67.

(I34) Foulley J. L., Menissier F., Gaillard J., Nebreda A. M., i976. Variabilité génétique des effets directs paternels sur la croissance, la conformation et les difficultés de naissance dans les races Blonde d'Aquitaine, Charolaise et Limousine utilisées en croisement pour la production de veaux de boucherie. I.N.R.A.-C.N.R.Z., 2 I p. (ronéotypé).

b) Young bull production (testing stations):

(i35) Frebi.ing J., Poujardieu B., Vissac B., Beranger C., Teissier J. H., ig67. Stations de sélection bovine. Compte rendu technique $\mathrm{n}^{\mathrm{o}} \mathbf{r}$. Note générale. Bull. tech. Inf., 225, $887-894$. 
(I36) Frebi,ing J., Poujardieu B., Vissac B., Beranger C., Teissier J. H., Rondeau M., 1967. Stations de sélection bovine. Compte rendu technique no 2 . Étude du croisement sur la race d'Aubrac (Essai Aubrac 1965). Bull. tech. Inf., 225, 895-906.

(i37) Frebling J., Poujardieu B., Vissac B., Beranger C., Teissier J. H., ig67. Stations de sélection bovine. Compte rendu technique $n^{\circ} 3$. Étude préliminaire du contrôle de descendance des taureaux Limousins sur les performances d'engraissement et d'abattage. Bull. tech. Inf., 225, 907-9r5.

(I38) Frebling J., Jouys P., Poujardieu B., Vissac B., i969. Stations de sélection bovine. Compte rendu technique $n^{\circ} 4$. Étude du contrôle de descendance des taureaux Limousins sur les performances d'engraissement et d'abattage. Bull. tech. Int., 236, 31-4I.

(r39) Gailiard J., Frebling J., Jouys P., Poujardieu B., Vissac B., 197o. Stations de sélection bovine. Compte rendu technique $n^{\circ} 5$. Contrôle de descendance des taureaux sur les performances d'engraissement et d'abattage. Bull. tech. Int., 248, 213-220.

(i4o) Frebling J., Poujardieu B., Vissac B., Azan M., Gail, ard J., Rondeau M., HenneQUIN M., I970. Stations de sélection bovine. Compte rendu technique n ${ }^{0} 6$. Comparaison des races Charolaise et Blonde d'Aquitaine en croisement de première génération sur la race d'Aubrac. Bull. tech. Inf., 248, 635-642.

3. - Analysis of direct and maternal effects (fertility, calving and maternal ability):

a) General papers:

(I4I) Bibe B., Bonnet J. N., Cavagne G., Menissier F., Sapa J., r974. Comparaison des critères de productivité numérique et pondérale de trois races bovines à viande françaises : résultats partiels et préliminaires. Ann. Génét. Sél. anim., 7, 1975, 235-236 (abstr.).

(I42) Fouliey J. L., Menissier F., Gaillard J., 1974. Aptitudes des races laitières, mixtes, rustiques et à viande pour la production de veaux de boucherie en ferme par croisement industriel. Ann. Génét. Sél. anim., 7, I975, 236-237 (abstr.).

(143) Foulizey J. I., Menissier F., Gailitard J., Nebreda A. M., r975. Aptitudes maternelles des races laitières, mixtes, rustiques et à viande pour la production de veaux de boucherie par croisement industriel. Livest. Prod. Sci., 2, 39-49.

b) Fevtility:

(144) Menissier F., Chupin D., Cheminant E., Fabre F., Fabre G. P., I974. Fertilité induite et sensibilité à la PMS-G de femelles culardes. I er Congr. Mond. Génét. appl. Élev., Madrid, 3, 8I -98.

(145) Menissier F., Frebling J., I974. Aptitude à la gémellité des races à viande françaises: observations en élevage et constitution d'un troupeau de sélection. Ann. Génét. Sél. anim., 1975, 7, 237 (abstr.).

\section{4. - Calving ability:}

(146) Ménissier F., Vissac B., ig69. Possibilités d'emploi des mesures de pelvimétrie interne pour la sélection des bovins. Ann. Génét. Sél. anim., 1, 90 (abstr.).

(147) ABDalfah O. Y., I97I. Variations génétiques de l'aptitude au vêlage et de ses composantes. Revue bibliographique. Bull. tech. Dépt. Génét. anim., 13, I80 p.

(I48) ABDALIAH O. Y., HADJEJ M. S., VisSAC B., I97I. Variations du comportement pré et post-partum entre races rustiques, races à viande et croisements de première génération. Io ${ }^{\mathrm{e}}$ Congr. Inter. Zootech., Versailles, juillet I97I, $6 \mathrm{p}$.

(I49) AbDalifah O. Y., Menissien F., Vissac B., I97I. Liaisons entre la musculature des races et leur aptitude morphologique au vêlage : résultats préliminaires. Io e Congr. Int. Zootech., Versailles, 4 p.

(i 5o) Couteaudier J. F., Regis R., Mínissier F., i97i. Possibilité de sélection de l'aptitude au vêlage en race Charolaise. Io Congr. Int. Zootech., Versailles, $6 \mathrm{p}$.

(I5I) Ménissier F., FABre G. P., I97I. Aptitude au vêlage et conditions de mise bas des génisses culardes Charolaises et Blondes d'Aquitaine. Io ${ }^{\mathrm{e}}$ Congr. Int. Ann. Génét. Sél. anim., 4, 128 (abstr.). 
(I52) Ménissiér F., Vissac B., r97r. Possibilités d'amélioration des conditions de vêlage par sélection. I. Technique de mesure de l'ouverture pelvienne des bovins. Ann. Génét. Sél. anim., 3, zо7-zi4.

(I53) Vissac B., Molinuevo H. A., Menissier F., I97I. Note sur l'évolution de la race Charolaise sous l'effet de la sélection. Ann. Génét. Sél. anim., 4, Iz8-1z9 (abstr.).

(r54) MÉnissier F., Bibé B., PERreau B., r973. L'aptitude au vêlage des génisses dans les croisements entre races à viande françaises : résultats préliminaires. Ann. Génét. Sél. anim., I974, 6, 145 (abstr.).

(i55) Ménisster F., Bibé B., Perreau B., r974. Calving ability of three french beef breeds: preliminary results. Livest. Prod. Sci., 1, 2 I 7-2 8.

(I56) Ménissięr F., Bibé B., Perreau B., I974. Possibilités d'amélioration des conditions de vêlage par sélection. II. L'aptitude au vêlage de trois races à viande françaises. $A n n$. Génét. Sél. anim., 6, 69-9o.

(I57) MÉnISsien F., I974. L'aptitude au vêlage des races à viande françaises. L'origine des difficultés de vêlage et leur amélioration génétique. VIes Journées d'information du "Grenier de Theix ", l'exploitation des troupeaux de vaches allaitantes, novembre I973. Suppl. Bull. tech., CRZV, Theix, no spéc. oct. 1974, 139-I 70.

(I 58) MÉnISSIER F., I975. Calving ability in French beef breeds: analysis of components and breeding improvement. Bull. tech. Dépt. Génét. anim., 21 "Optimum breeding plans for beef cattle ", 57-102.

(159) Taylor St. C. S., Monteiro L. S., Perreau B., r975. Possibility of reducing calving difficulties by selection. III. A note on pelvic size in relation to body weight of cattle. Ann. Génét. Sél. anim., 7, 49-57.

(i6o) FOUlLEY J. I., MÉNISSIER F., I977. Selection on calving ability in French beef breeds. EEC Seminar on calving problems and early viability of the calf. Session 2. Genetic factors and breeding for calving performance. Freising, 4-6 may, 1977, 20 p.

(I6I) MÉnissier F., Foulley J. L., I977. Present situation of calving problems in the EEC: Incidence of calving difficulties and early calf mortality in the beef herds. EE, Seminar on calving problems and early viability of the calf. Session I. Survey of present situation in $\mathrm{EEC}$, Freising, 4-6 may, 1977, 46 p.

5. - Maternal ability:

(I62) Foul. EYY J. L., MÉnissier F., I974. Variabilité génétique des caractères de production des femelles charolaises contrôlées en station : résultats préliminaires. VIes Journées d'information du "Grenier đe Theix " : l'exploitation des troupeaux de vaches allaitantes, novembre 1973. Suppl. Bull. tech., CRZV, Theix, no spé,, oct. I974, I7I-I91.

\section{B. - OTHER PAPERS}

(i63) Angei, H., Poly J., 1956. Facteurs affectant le poids à la naissance des veaux. Ann. Zootech., 5, 73-86.

(164) Auriol P., Dumont B. L., Duplan J. M., 1959. Étude des performances de la race Charolaise. C. R. Acad. Agr. Fr., 45, I I I-I23.

(i65) Vissac B., Beranger C., I969. Phénomène d'interaction génotype $\times$ milieu dans l'élevage des bovins à viande en zone de montagne. Ann. Génét. Sél. anim., 1, 192-193 (abstr.).

(I66) Molinuevo H. A., I97x. Variabilité génétique de la croissance avant sevrage dans les races Charolaise et Limousine. Thèse doct. $3^{\mathrm{e}}$ cycle, Paris, $44 \mathrm{p}$.

(i67) Colieau J. J., Menissier F., Monteiro S., Vissac B., i973. Tendances actuelles de l'expérimentation en matière de sélection bovine. Ann. Génét. Sél. anim., 5, 147-153. 


\section{3rd part: Breeding improvement}

I. - General papers:

(168) Vissac B., I970. Étude génétique de la race d'Aubrac. " L'Aubrac, étude éthnologique, linguistique, agronomique et économique d'un établissement humain ". C.N.R.S., Paris, 27-IOI.

(169) Vissac B., 197I. Amélioration génétique des bovins en régions tropicales et subtropicales. Colloque sur 1'élevage, Fort-Lamy, 484-494.

( I 70) VISSAC B., I973. Optimal use of genetic material to increase profit in beef cattle (French examples). Irish Grassland and Animal Production Association, Conference, Dublin, $20 \mathrm{p}$.

(I7I) Ménissier F., Vissac B., Frebling J., I974. Plans optimaux de production bovine : l'amélioration génétique de la production de viande dans les troupeaux spécialisés et par croisement dans les troupeaux laitiers. Ann. Génét. Sél. anim., 7, 229-23o (abstr.).

(r 72) Boyazoglu J. G., 1975. Beef breeding and selection systems in France. Anim. Breed. Abstr., 43, 167-174.

(173) Casu S., Boyazoglu J. G., BibÉ B., Vissac B., I975. Systèmes d'amélioration génétique de la production de viande bovine dans les pays méditerranéens: les recherches sardes. Bull. tech. Dépt. Génét. anim., 22, $50 \mathrm{p}$.

(174) MúnISSIFR F., I975. Genetic aspects related to use of beef breeds. E.C. Seminar: "The early calving of heifers and its impact on beef production; C.E.C., Eur 5545 E, 81-I 27 .

(175) Ménissier F., Vissac B., Frebling J., i 975. Optimum production plans for milk and meat: specialized beef herds and beef crossing in dairy herds. Bull. Tech. Dépt. Génét. anim., 21, "Optimum breeding plans for beef cattle ", 2-56.

(I76) VISSAC B., I975. Optimizing sheep and cattle breeding in the EEC with special reference to France. Proc. Aust. Soc. Anim. Prod., 11, 527-537.

(I77) Bibí, B., Frebling J., Mf́nissier F., Vissac B., 1977. Optimal crossbreeding plans. In "Crossbreeding experiments and strategy of breed utilization to increase beef production ". C.E.C. Seminar, Verden, February 9-I I, 1976, I 5 p.; C.E.E. Eur, 5492 E, 34-54.

( I 78) Bibé B., Frébling J., MÉnissier F., PERreau B., I977. French crossbreeding experiment between beef breeds. In "Crossbreeding experiments and strategy of breed utilization to increase beef production ". C.E.C. Seminar, Verden, february 9-II, I976; C.E.C., Eur $5492 \mathrm{E}, \mathrm{I} 74-195$.

(i 79) Vissac B., Bibé B., Frebling J., Ménissier F., Casu S., Boyazoglu J. G., i976. Potentialités des populations bovines en élevage extensif dans les zones montagneuses et méditerranéennes. Options méditerranéennes, 35, 76-9o.

(i 8o) Bibí B., Foulífy J. L., I976. Effets d'hétérosis chez les bovins à viande : résultats bibliographiques. Bull. tech. Dépt. Génét. anim. (Inst. nat. Rech. agron., Fr.), 24, 87-1 ro.

2. - Scheme for terminal crossing:

(I 8I) VISSAC B., 1959. Rapport sur les recherches françaises intéressant le testage des taureaux sur les aptitudes à la production de viande de leurs descendants, Fédération Européenne de Zootechnie, Belgrade, In : Bergström. Mise à l'épreuve de la descendance des taureaux dans les races bovines productrices de viande, $72-125$.

(i 82) Vissac B., Poly J., Charlete P., 1959. Les épreuves de descendance des taureaux d'insémination sur la valeur de leurs veaux de boucherie. Bull. tech. Inf., 145, 759-787.

(i83) Auriol P., Dupont B. L., LEFebvre J., Duplan J. M., I96I. Caractéristiques générales des vaches charolaises et croissance de leurs produits. France Élevage Charolais, 3, I-28.

(184) Arnaud A., r964. Application du test de comparaison de deux moyennes d'une série ordonnée au classement des taureaux sur descendance. Ann. Zootech., 13, 173-18I.

(185) Vissac B., I964. Méthode de détermination de l'index génotypique des taureaux d'insémination sur la valeur de leurs veaux de boucherie. Ann. Zootech., 13, 267-275. 
(186) VISSAC B., I966. L'utilisation du Charolais en croisement avec des races à fins multiples pour améliorer la production de viande de jeune bovin. Journées techniques internationales charolaises, Vichy. Charolais, 4, i 8-29.

(I87) VISSAC B., I967. Note relative à la comparaison des descendances de taureaux dans le cas d'épreuves discontinues. Ann. Zootech., 16, 335-34r.

(is8) Foulley J. I., Molinuevo H. A., I97I. Possibilités de modification par sélection de la forme de la courbe de croissance avant sevrage des veaux de races à viande françaises. Fédération Européenne de Zootechnie, Versailles, 6 p.

(189) Foulley J. L., RouvieR R., I971. Méthode d'établissement des index de sélection des taureaux de races à viande sur la valeur économique de leurs descendants. Ann. Génét. Sél. anim., 3, 495-507.

(190) ANONymE, I972. Efficacité réelle et optimum du choix des taureaux de race à viande pour le croisement industriel. Bull. Tech. Dépt. Génét. anim., 15, 76 p.

(I9I) VISSAC B., 1972. Sélection de souches mâles de bovins à viande pour le croisement terminal. Bull. tech. Dépt. Génét. anim., 15, I-22.

(192) Colleau J. J., Foulley J. L., Gaillard J., i974. Le lot témoin dans le contrôle des taureaux de races à viande françaises sur descendance croisée : intérêt pour la mesure du progrès génétique. Ann. Génét. Sél. anim., 6, 24I-252.

(193) Gailifard J., Foulifey J. L., Ménissier F., I974. Observations sur l'efficacité du choix sur ascendance paternelle et performances individuelles des taureaux de races à viande destinés au croisement terminal. I ${ }^{\text {er }}$ Congr. Mond. Génét. appl. Élev., Madrid, 1, 307-320.

(194) Foutıley J. I., Gailitard J,, I975. Utilisation du lot témoin dans les schémas de sélection des taureaux de races à viande pour le croisement industriel : principes et résultats. Bull. tech. Dépt. Génét. anim., 19 : mesure du progrès génétique réalisé par sélection sur les animaux de ferme, 6o-68.

(195) FouLLEY J. L., 1976. Some considerations on selection criteria and optimization for terminal sire breeds. In: Optimization of cattle breeding schemes, C.E.C. Seminar, Dublin, November 26-28, I975; C.E.C. Eur. 5490 E, 85-I04.

(196) FoUL,LEY J. I., I976. Some considerations on selection criteria and optimization for terminal sire breeds. Ann. Génét. Sél. anim., 8, 89-1or.

\section{3. - Other breeding schemes (Chiefly purebreeding):}

(197) MÉnissier F., VISSAC B., I974. L'amélioration des performances d'élevage de la race Charolaise : les recherches françaises. Semaine internationale charolaise, septembre 1974, Vichy, $34 \mathrm{p}$.

(198) MÉNISSIER F., I976. Comments on optimization of cattle breeding schemes: beef breeds for suckling herds. In " Optimization of cattle breeding schemes ", C.E.C., Eur. $549^{\circ}$ E, I25-I 52.

(199) MÉNISSIER F., I976. Comments on optimization of cattle breeding schemes: beef breeds for suckling herds: a review. Ann. Génét. Sél. anim., 8, 7I-87.

(200) MÉNISSIER F. Comments on optimization of cattle breding schemes: beef breeds for suckling herds. In "Optimization of cattle breeding schemes ", C.E.C. Seminar, Dublin, November 26-28, 1975; Ann. Génét. Sél. anim., 8, 71-87.

4. - Optimization of breeding schemes:

(20I) Poutous M., VISSAC B., I962. Recherche théorique des conditions de rentabilité maximum de l'épreuve de descendance des taureaux d'insémination artificielle. Ann. Zootech 11, $233-256$.

(202) MOCQUOT J. C., FOULLEY J. L., 1973. Recherche des conditions de rentabilité d'un schéma de sélection d'une souche de bovins destinée au croisement de première génération pour la production de veaux de boucherie. Ann. Génét. Sél. anim., 5, I89-209.

(203) EISEN J. M., MocQvot J. C., I974. Recherches pour une rationalisation technique et économique des schémas de sélection des bovins et ovins. Bull. tech. Dépt. Génét. anim., $17,97 \mathrm{p}$. 
(204) ELSEN J. M., I976. Sélection dans les populations bovines de type mixte : application d'un nouvel algorithme à l'estimation des pondérations économiques des indices de sélection. Ann. Génét. Sél. anim., 9, 73-85.

(205) ELSEN J. M., Mocquor J. C., r976. Intérêt de la transplantation d'œufs pour accroître l'efficacité de la sélection des bovins à viande. Ann. Génét. Sél. anim., 8, 331-342.

(206) ElsEN J. M., Mocevot J. C., 1976. Optimisation du renouvellement des femelles dans les troupeaux laitiers soumis au croisement terminal. Ann. Génét. Sél. anim., 8, 343-356.

(207) FOULLEY J. L., ELSEN J. M., 1977. Relations a priori entre le BLUP, la méthode de comparaison aux contemporaines et les méthodes des différences cumulées en vue de l'évaluation des mâles. Ann. Génét. Sél. anim., 9, 307-326.

5. - Crossbreeding systems:

(208) VIsSAC B., I97I. L'utilisation optimale du matériel génétique. Les apports des techniques de croisement par rapport aux autres méthodes d'amélioration génétique : bovins à viande (troupeaux spécialisés). Fédération Européenne de Zootechnie, Versailles, 69-8r.

(209) BibÉ B., Frebling J., MÉnISSIER F., I973. Schéma d'utilisation des races rustiques en croisement avec des races à viande. Ann. Génét. Sél. anim., 6, I44 (abstr.).

(zio) Vissac B., Boyazoglu J. G., Santa Coloma L., 1973. L'utilisation de la race Charolaise dans les troupeaux de vaches allaitantes en zones tempérées. In: "La race charolaise. I. Résultats étrangers ". Bull. tech. Dépt. Génét. anim., 15, I-22.

(2I I) BibÉ B., FREBling J., Mł́nISSIER F., VISSAC B., 1976. Schéma d'utilisation des races rustiques en croisement avec des races à viande : exemple de la race Gasconne. Ann. Génét. Sél. anim., 8, 233-264.

(2 12) Vissac B., r976. Possibilités et limites d'utilisation des races à fort potentiel de croissance musculaire pour améliorer la production de viande bovine dans le monde. World Rev. Anim. Prod., 19, I-7.

These references are ordered according to the plan of the review and for each section under a chronological scale; they are limited to original papers and scientific reports published in reviews and congresses. Students theses which sometimes represent the first flow of further scientific results are not mentioned in these references. 